\title{
The effects of customer equity drivers on loyalty across services industries and firms
}

\author{
Yi-Chun Ou ${ }^{1} \cdot$ Peter C. Verhoef $^{2} \cdot$ Thorsten Wiesel $^{3,4}$
}

Received: 26 March 2015 / Accepted: 17 February 2016/Published online: 11 March 2016

(C) The Author(s) 2016. This article is published with open access at Springerlink.com

\begin{abstract}
Customer equity drivers (CEDs) - value equity, brand equity, and relationship equity - positively affect loyalty intentions, but this effect varies across industries and firms. We empirically examine potential industry and firm characteristics that explain why the CEDs-loyalty link varies across services industries and firms in the Netherlands. The results show that (1) some previously assumed industry and firm characteristics have moderating effects while others do not and (2) firm-level advertising expenditures constitute the most crucial moderator because they influence all three loyalty strategies (significant for value equity and brand equity; marginally significant for relationship equity), while three industry contexts (i.e., innovative markets, visibility to others, and
\end{abstract}

Mark Houston served as area editor for this article.

Electronic supplementary material The online version of this article (doi:10.1007/s11747-016-0477-6) contains supplementary material, which is available to authorized users.

Yi-Chun Ou

busyou@leeds.ac.uk

Peter C. Verhoef

p.c.verhoef@rug.nl

Thorsten Wiesel

thorsten.wiesel@wiwi.uni-muenster.de

1 Marketing Division, University of Leeds, Leeds LS2 9JT, UK

2 Department of Marketing, Faculty of Economics and Business, University of Groningen, P.O. Box 800, 9700

AV Groningen, The Netherlands

3 Marketing Center Münster, Westfälische Wilhelms-Universität Münster, Am Stadtgraben 13-15, 48143 Münster, Germany

4 Department of Marketing, Faculty of Business and Economics, University of Groningen, Groningen, The Netherlands complexity of purchase decisions) each influence two of the three loyalty strategies. Our results clearly show that specific industry and firm characteristics affect the effectiveness of specific loyalty strategies.

Keywords Customer loyalty $\cdot$ Customer relationship management $\cdot$ Customer equity $\cdot$ Brand equity $\cdot$ Multi-level analysis

\section{Introduction}

With markets becoming increasingly competitive, firms are devoting considerable attention to the issue of loyal customers - specifically, how to attain them and maximize their value (e.g., Watson et al. 2015). Among the many studies that have tried to better understand customer loyalty, one of the most influential is the study of Rust et al. (2000) and their customer equity model. Their follow-up article (i.e., Rust et al. 2004) further solidifies the value of said model among academics. The Rust et al. (2000) model proposes that three customer equity drivers (CEDs) are crucial components of loyalty intentions: value equity (VE), brand equity (BE), and relationship equity (RE). ${ }^{1}$ In turn, research has provided convincing support for the proposed impact of CEDs; for

\footnotetext{
${ }^{1}$ In this study, "loyalty intentions" refer to customers' self-reported probabilities of repurchasing from competing firms within an industry, i.e., measuring the loyalty shares among the competing firms (Rust et al. 2004). VE is defined as customers' objective assessment of what is given up for what is received; $\mathrm{BE}$ is customers' subjective assessment of brand image; RE is customers' overall assessment of their interaction quality with firms (Lemon et al. 2001; Rust et al. 2004). Rust et al. (2000) label $\mathrm{RE}$ as retention equity, but later work re-labels this concept as relationship equity to better reflect the substantive concept.
} 
example, Ou et al. (2014) generalize this positive link to 13 services industries.

Despite the positive support for a CEDs-loyalty link, studies have widely indicated that loyalty strategies are not equally effective across industries and firms (e.g., De Haan et al. 2015; Eisenbeiss et al. 2014; Kumar et al. 2013; Rust et al. 2004). Ou et al. (2014) empirically show that there are substantial variations in the effects of CEDs across industries and firms. However, explanations for cross-industry and cross-firm variations remain scarce. As Table 1 shows, multiple studies have investigated the cross-customer variation in the effectiveness of customer loyalty determinants (i.e., satisfaction, commitment, and trust). They examine, for example, demographics, relationship length, switching costs, and consumer confidence as customer-level moderators to explain the variation (e.g., Mittal and Kamakura 2001; Ou et al. 2014). Studies have also investigated industry-level (e.g., Seiders et al. 2005) or firmlevel (i.e., Verhoef et al. 2007) moderators. Overall, however, few industry- and firm-level moderators have been systematically identified and empirically examined. This constitutes a research gap in the customer relationship management (CRM) literature. Examining this gap is crucial because situational theory indicates that identifying the contexts relevant to individual reactions is as important as understanding individual cognitive processes; it also assumes that customers in different contexts employ different comparison standards in decision making (Eisenbeiss et al. 2014; Longshore and Prager 1985) Thus, our main objective is to develop a framework of industry and firm characteristics as moderators and empirically examine the extent to which they explain cross-industry and cross-firm variations on the link between CEDs and loyalty intentions.

Rust et al. (2000) initially discussed some industry characteristics as moderators. They argued that VE is more important for homogeneous markets, BE for visible goods/services, and RE for contractual settings. Building on their discussion and the CRM literature, we derive multiple important industryand firm-level moderators and theorize their impact on the link between CEDs and loyalty. In the following section, we further detail how we select these moderators and formulate the hypotheses. Next, we use three data sources to examine the impact of these moderators: (1) a large-scale customer dataset (including 8924 customer responses of 95 leading companies across 18 services industries in the Netherlands), (2) an expert survey consisting of 178 responses from 88 managers and business consultants, and (3) external sources, including data from ACNielsen on firms' annual advertising expenditures and from firms' annual revenue reports. We use a multi-level model with four levels to estimate the proposed moderating effects.

Overall, this study provides three contributions to the extant literature. The first contribution pertains to a research gap

Table 1 Prior empirical studies regarding the moderators on the effects of CEDs

\begin{tabular}{|c|c|c|c|c|c|c|c|}
\hline \multirow[t]{2}{*}{ Studies } & \multicolumn{3}{|c|}{ Main effects } & \multicolumn{3}{|l|}{ Moderators } & \multirow[b]{2}{*}{$\begin{array}{l}\text { Country } \\
\text { characteristics }\end{array}$} \\
\hline & $\mathrm{VE}$ & $\mathrm{BE}$ & $\mathrm{RE}$ & $\begin{array}{l}\text { Customer } \\
\text { characteristics }\end{array}$ & $\begin{array}{l}\text { Firm } \\
\text { characteristics }\end{array}$ & $\begin{array}{l}\text { Industry } \\
\text { characteristics }\end{array}$ & \\
\hline Mittal and Kamakura (2001) & $\checkmark$ & & & $\checkmark$ & & & \\
\hline Verhoef et al. (2002) & $\checkmark$ & & $\checkmark$ & $\checkmark$ & & & \\
\hline Nijssen et al. (2003) & $\checkmark$ & & $\checkmark$ & & & $\checkmark$ & \\
\hline Gustafsson et al. (2005) & $\checkmark$ & & $\checkmark$ & $\checkmark$ & & & \\
\hline Seiders et al. (2005) & $\checkmark$ & & & $\checkmark$ & & $\checkmark$ & \\
\hline Bell et al. (2005) & $\checkmark$ & & & $\checkmark$ & & & \\
\hline Cooil et al. (2007) & $\checkmark$ & & & $\checkmark$ & & & \\
\hline Chandrashekaran et al. (2007) & $\checkmark$ & & & $\checkmark$ & & & \\
\hline Verhoef et al. (2007) & $\checkmark$ & $\checkmark$ & $\checkmark$ & & $\checkmark$ & & \\
\hline Voss et al. (2010) & $\checkmark$ & & & $\checkmark$ & & $\checkmark$ & \\
\hline Eisenbeiss et al. (2014) & $\checkmark$ & & & $\checkmark$ & $\checkmark$ & & \\
\hline Frank et al. (2014) & $\checkmark$ & $\checkmark$ & $\checkmark$ & $\checkmark$ & & $\checkmark$ & $\checkmark$ \\
\hline Nagengast et al. (2014) & $\checkmark$ & & & $\checkmark$ & & & \\
\hline Ou et al. (2014) & $\checkmark$ & $\checkmark$ & $\checkmark$ & $\checkmark$ & & & \\
\hline Keiningham et al. (2015) & & & $\checkmark$ & & & $\checkmark$ & \\
\hline Summary of previous studies & $14 / 15^{\mathrm{a}}$ & $3 / 15^{\mathrm{a}}$ & $7 / 15^{\mathrm{a}}$ & $12 / 15^{\mathrm{a}}$ & $2 / 15^{\mathrm{a}}$ & $5 / 15^{\mathrm{a}}$ & $1 / 15^{\mathrm{a}}$ \\
\hline Current study & $\checkmark$ & $\checkmark$ & $\checkmark$ & $\checkmark$ & $\checkmark$ & $\checkmark$ & $x$ \\
\hline
\end{tabular}

${ }^{\mathrm{a}}$ In these fractions, the denominator refers to the number of previous studies included in Table 1; the numerator refers to the number of topics studied in the previous studies. Take VE as a main effect for illustration. Fourteen out of fourteen studies have examined VE as a main effect 
in theorizing and testing the contextual moderators in CRM. Specifically, we theoretically explain cross-industry and cross-firm variations of the effectiveness of CEDs by identifying a framework of multiple industry and firm characteristics. Consequently, we empirically show that the effects of CEDs are indeed influenced by some theoretically assumed industry and firm characteristics. For example, the effect of RE decreases in innovative markets and for heavy advertisers. This is a significant contribution in the CRM literature, which currently lacks a systematic investigation of industry- and firm-level moderators' impacts (Kumar et al. 2013; Rust et al. 2004).

The second contribution is on the methodological level. We use multiple data sources, including customer data, expert data, and secondary data, which allow us to explore how customers react to different contexts and to achieve a better understanding of how these reactions ultimately influence the role of CEDs on customers' loyalty decisions in specific contexts. We also control for customer-level moderators while investigating the joint moderating effects of industry- and firm-level characteristics on the link between CEDs and loyalty intentions. To our knowledge, no studies have simultaneously included all three levels as moderators. This is a critical gap because prior research has indicated that customers' decision making is influenced by their personal characteristics and also their economic system (Johns 2006; Molloy et al. 2010).

The third contribution is managerial. Our findings help managers across different services industries determine which industry and firm characteristics actually have a contingent impact and which loyalty strategies are most/least effective in a specific context. At the industry level, we provide more insight into how firms should adapt CEDs to their industry environment to enhance loyalty intentions. For example, while firms are able to use RE to increase loyalty intentions by $15 \%$ on average, this effect decreases to $7.6 \%$ in innovative markets. At the firm level, we provide more insight into how firms should effectively combine CEDs and their specific firm characteristics. For example, the average effect $(15 \%)$ of using RE decreases to $11.4 \%$ for heavy advertisers. A study that closely parallels our own is that of Ou et al. (2014), though our work differs in several ways. Specifically, we have a different aim (moderating role of industry and firm characteristics vs. moderating role of consumer confidence only), simultaneously incorporate moderators at several levels (multiple industry-, firm- and customer-level moderators vs. only one customer-level moderator), and apply multiple datasets. We also adopt a new consumer survey, an expert survey, and external sources and provide more nuanced insights relevant for managers. ${ }^{2}$

\footnotetext{
${ }^{2}$ In Web Appendix A, we further outline the similarities and differences between the current study and Ou et al. (2014).
}

\section{Theoretical background and hypotheses}

Rust et al.'s (2000) customer equity model identifies (1) value equity, (2) brand equity, and (3) relationship equity as three drivers of loyalty intentions. We adopt the definitions of CEDs from Lemon et al. (2001) and Rust et al. (2004). VE captures customers' objective assessments of the utility of goods/ services based on perceptions of "what is given up" for "what is received." VE reflects the outcome of customers' comparisons between their own expectations and firms' performance. Expectation-disconfirmation theory (e.g., Homburg et al. 2006) argues that customers are more satisfied with a firm's offerings when they perceive high VE, which leads to higher loyalty intentions. BE refers to customers' subjective and intangible assessments of the brand image. We view brand image as brand strength and brand innovativeness in this study, as both are main criteria of adding value to brands (BrandZ 2015; Rooney 2014) and are important drivers of customerbased BE (e.g., Mizik and Jacobson 2003). Theoretically, the effect of BE on loyalty intentions could be well explained by signal credibility and the best "fit." ${ }^{3}$ Signal credibility of strong brands reduces the perceived performance risk of goods/services (Erdem et al. 2006), thereby inducing higher loyalty intentions. The best "fit" (Rust et al. 2000) explains that customers tend to prefer a brand when they perceive a fit between brand image and their self-image and personality (e.g., status and social identity). Last, RE captures customers' overall assessments of their interaction quality with the firm. On the basis of reciprocity, customers perceiving good relationships with firms tend to care about firms' welfare and to avoid any decision that might damage firms (Aurier and N'Goala 2010; Selnes and Gønhaug 2000). As a result, if perceived RE is high, customers feel a strong connection with the firm, which has a positive effect on loyalty intentions.

Although CEDs may positively affect loyalty intentions, Rust et al. (2000) suggest that the effects may strongly differ between industries. Ou et al. (2014) confirm strong variations of the effects of CEDs across industries; they also reveal variations in these effects between firms. Studies (e.g., Kumar et al. 2013) have also acknowledged the differential effects of customer attitudes (i.e., satisfaction) across industries and firms. According to situational theory, customers in different contexts tend to employ different comparison standards in decision making (Eisenbeiss et al. 2014; Longshore and Prager 1985). Each industry/firm has its own characteristics that customers commonly evaluate (Mauri and Michaels 1998). As such, customers within an industry/a firm may behave similarly. Unique industry/firm characteristics shape customers' preferences and decision patterns. Situational theory

\footnotetext{
${ }^{3}$ This study uses signal credibility and the best "fit" to explain the mechanisms by which BE influences loyalty intentions. We do not empirically test these two mechanisms of BE.
} 
also indicates that identifying the contexts relevant to individual reactions is as important as understanding individuals' cognitive processes. Thus, it is necessary to derive a robust framework of important industry and firm characteristics to examine the differential effectiveness of CEDs in specific contexts. In the following, we discuss how we selected industry and firm characteristics.

\section{Moderator selection and conceptual model}

Because many potential industry and firm characteristics exist, we used four steps to select these characteristics for the purpose of explaining the concerned cross-industry and crossfirm variations. The selection is based on Rust et al.'s (2000) proposed moderator framework and available knowledge on industry/firm moderators in the CRM literature (see Table 2).

In the initial step, we critically evaluated Rust et al.'s (2000) presumed moderators and their testability. First, customer involvement is more of a customer- than an industrylevel moderator and has already been tested in prior studies (e.g., Homburg and Giering 2001). Thus, we included customer involvement in our model as a customer-level control variable. Second, some moderators tend to be relevant to RE. For example, as Rust et al. (2000) argue that customers receive large benefits from $\mathrm{RE}$, the implication then follows that firms find wisdom in steering RE and providing large benefits (i.e., through loyalty programs; Dorotic et al. 2012) to maintain loyalty. Furthermore, a strong brand community between customers tends to involve customer commitment (Bagozzi and Dholakia 2006), which is one component of RE (Rust et al. 2000). Therefore, we do not include these two suggested moderators in the model. Third, some moderators are rather difficult to test and/or are not applicable in consumer services industries (e.g., business-to-business [B2B] settings), and our focus is on consumer markets. For example, the importance of recycling seems more important in product industries. This issue is also common among intergenerational brands (e.g., cars). Thus, we initially selected seven of Rust et al.'s (2000) presumed moderators: (1) the presence of differences between competitors, (2) the importance of customer learning, (3) the difficulty of evaluating quality prior to consumption, (4) innovative markets, (5)

Table 2 Steps of selecting industry- and firm-level moderators

\begin{tabular}{|c|c|c|c|c|}
\hline Moderators & Step 1 & Step 2 & Step 3 & Step 4 \\
\hline \multicolumn{5}{|c|}{ Industry-level moderators from Rust et al. (2000) } \\
\hline Customer involvement & $\begin{array}{l}\text { Excluded: included as a customer- } \\
\text { level variable }\end{array}$ & - & - & - \\
\hline $\begin{array}{l}\text { Benefits associating with loyalty } \\
\text { programs }\end{array}$ & $\begin{array}{l}\text { Excluded: tend to be relevant to } \\
\text { RE }\end{array}$ & - & - & - \\
\hline $\begin{array}{l}\text { Strong communities associating with } \\
\text { goods/ services }\end{array}$ & $\begin{array}{l}\text { Excluded: tend to be relevant to } \\
\text { RE }\end{array}$ & - & - & - \\
\hline B2B settings & Excluded: not our focus & - & - & - \\
\hline $\begin{array}{l}\text { Recycling of products in the mature } \\
\text { stage }\end{array}$ & $\begin{array}{l}\text { Excluded: more important in } \\
\text { product industries }\end{array}$ & - & - & - \\
\hline Inter-generational brands & $\begin{array}{l}\text { Excluded: more important in } \\
\text { product industries }\end{array}$ & - & - & - \\
\hline $\begin{array}{l}\text { Presence of differences between } \\
\text { competitors }\end{array}$ & Included & Included & Excluded: a characteristic of competitive intensity & - \\
\hline Importance of customer learning & Included & Included & $\begin{array}{l}\text { Excluded: related to difficulty of evaluating quality } \\
\text { prior to consumption }\end{array}$ & - \\
\hline $\begin{array}{l}\text { Difficulty of evaluating quality prior } \\
\text { to consumption }\end{array}$ & Included & Included & $\begin{array}{l}\text { As a control variable because we aim at existing } \\
\text { customers }\end{array}$ & - \\
\hline Innovative markets & Included & Included & Included & Included \\
\hline Contractual settings & Included & Included & Included & Included \\
\hline Visibility to others & Included & Included & Included & Included \\
\hline Complexity of purchase decisions & Included & Included & Included & Included \\
\hline \multicolumn{5}{|c|}{ Industry-level moderators from the CRM literature } \\
\hline Competitive intensity & - & Included & Included & Included \\
\hline Market dynamics & - & Included & Excluded: related to innovative markets & - \\
\hline \multicolumn{5}{|l|}{ Firm-level moderators } \\
\hline Market position & - & - & - & Included \\
\hline Advertising expenditures & - & - & - & Included \\
\hline
\end{tabular}

$-:$ not considered

Bold: the moderators chosen for this manuscript 
contractual settings, (6) visibility to others, and (7) the complexity of purchase decisions.

In the second step, we considered the existing literature on CRM. We mainly found studies that discuss the moderating role of competitive intensity and market dynamics (e.g., Seiders et al. 2005; Voss et al. 2010), which are also included. In the third step, we critically evaluated the resulting nine industry-level moderators to determine any theoretical overlap among them (Evans 1991). For example, competitive intensity and the presence of differences between competitors are strongly related, as competition is usually more intense in industries with homogeneous goods/services (Menguc and Auh 2006). As competitive intensity is a frequently studied and well-established industry moderator, we focused on that factor. Next, the difficulty of evaluating quality prior to consumption and the importance of customer learning are related. If customers face problems with evaluating goods/services, they eventually learn about the performance of these goods/ services during consumption. Given this theoretical overlap, we focused on the difficulty of evaluating quality prior to consumption, as this concept is more clearly discussed in the literature (e.g., Fischer et al. 2010). However, this moderator may have less impact on existing customers, who are the main respondents of this study. Therefore, we used the moderator as a control variable. Finally, we expect that innovative markets and market dynamics are two sides of the same coin: firms in dynamic markets rapidly introduce innovative goods/services to meet sudden changes in customer demand (Slater and Narver 1994). In other words, rapidly introducing innovative goods/services is a phenomenon of innovative markets. Thus, we chose to focus on innovative markets, as this moderator is discussed more heavily in Rust et al.'s (2000) framework. In summary, we chose to investigate five industry moderators: (1) innovative markets, (2) contractual settings, (3) visibility to others, (4) complexity of purchase decisions, and (5) competitive intensity.

Researchers maintain that contexts at the meso- and microlevels play a role in influencing the relationships we examine (Bamberger 2008). In addition to industry characteristics, prior research has uncovered heterogeneity between firms regarding the effect sizes of CEDs on loyalty intentions $(\mathrm{Ou}$ et al. 2014). In the fourth step, given industry characteristics as the meso-level context influencing customer perceptions of loyalty strategies, we assume that firm characteristics lie at the micro-level; therefore, we also included firm characteristics in our framework. We chose to include two firm characteristics as crucial marketing variables: (1) market position and (2) firm-level advertising expenditures. Many firms strive to be market leaders, while they also use advertising to differentiate themselves from competitors (e.g., Fischer et al. 2016).

Regarding market position, research assumes that market leaders have more advantages over followers. For example, when market leaders promote goods/services, they have a greater influence on competitors/followers and draw followers' market share. In turn, followers' promotions do not easily influence leaders' market share (Hoeffler and Keller 2003). However, there is a strong debate within CRM about whether brands with a high market share can actually benefit from loyalty-based strategies (e.g., Dowling and Uncles 1997; Ehrenberg et al. 1990). As a result, how to choose effective context-specific loyalty strategies is still an unresolved puzzle for both market leaders and followers.

Regarding firm-level advertising expenditures, market power theory argues that heavy advertisers are able to improve brand recognition and reputation to charge higher prices and maintain a given scale of sales (e.g., Kaul and Wittink 1995), assuming a strengthened effect of BE and weakened effect of VE for heavy advertisers. Despite BE and VE, customer relationships are crucial for building strong ties for services industries (e.g., Mende et al. 2013). However, little is known about how firm-level advertising expenditures might influence the effect of CRM. As a result, because decisions about the amount of money to spend on advertising influence firm performance (Fischer et al. 2016), we take an initial step of empirically examining the interaction effects of firm-level advertising expenditures and CEDs on loyalty intentions.

Figure 1 depicts the resulting conceptual model. As the model shows, CEDs are positively related to loyalty intentions; however, five industry characteristics and two firm characteristics moderate these relationships. To account for potential omitted variable bias, we included the main effects and also the moderation effects of several control variables.

Next, we hypothesize the impact of the industry and firm characteristics on the link between CEDs and loyalty intentions. Drawing on multiple theories in the CRM literature, we develop the hypotheses by exploring how customers react to these contexts and theorizing how these reactions, in turn, influence the role of CEDs on customers' loyalty decisions in specific contexts.

We did not hypothesize the moderating impact of the industry and firm characteristics on all CEDs, as some impacts are rarely theorized or mentioned in the CRM literature. Having no strong underlying theories or empirical findings may give uncertain directions of the moderating impact. As such, we left some moderating impacts open as an empirical question. For example, prior studies have mainly found a weakened effect of VE in competitive industries and paid little attention to the impact of competitive intensity on the effects of BE and RE (e.g., Seiders et al. 2005; Voss et al. 2010). Thus, we have little idea of how competitive intensity moderates the effects of BE and RE. On the one hand, we might surmise that $\mathrm{BE}$ and $\mathrm{RE}$ are more important in competitive industries, as both are difficult to imitate and should be important differentiators for firms in competitive industries (Rust et al. 2000). On the other hand, we might assume that BE and RE are less important in competitive industries, as 
Fig. 1 Conceptual model

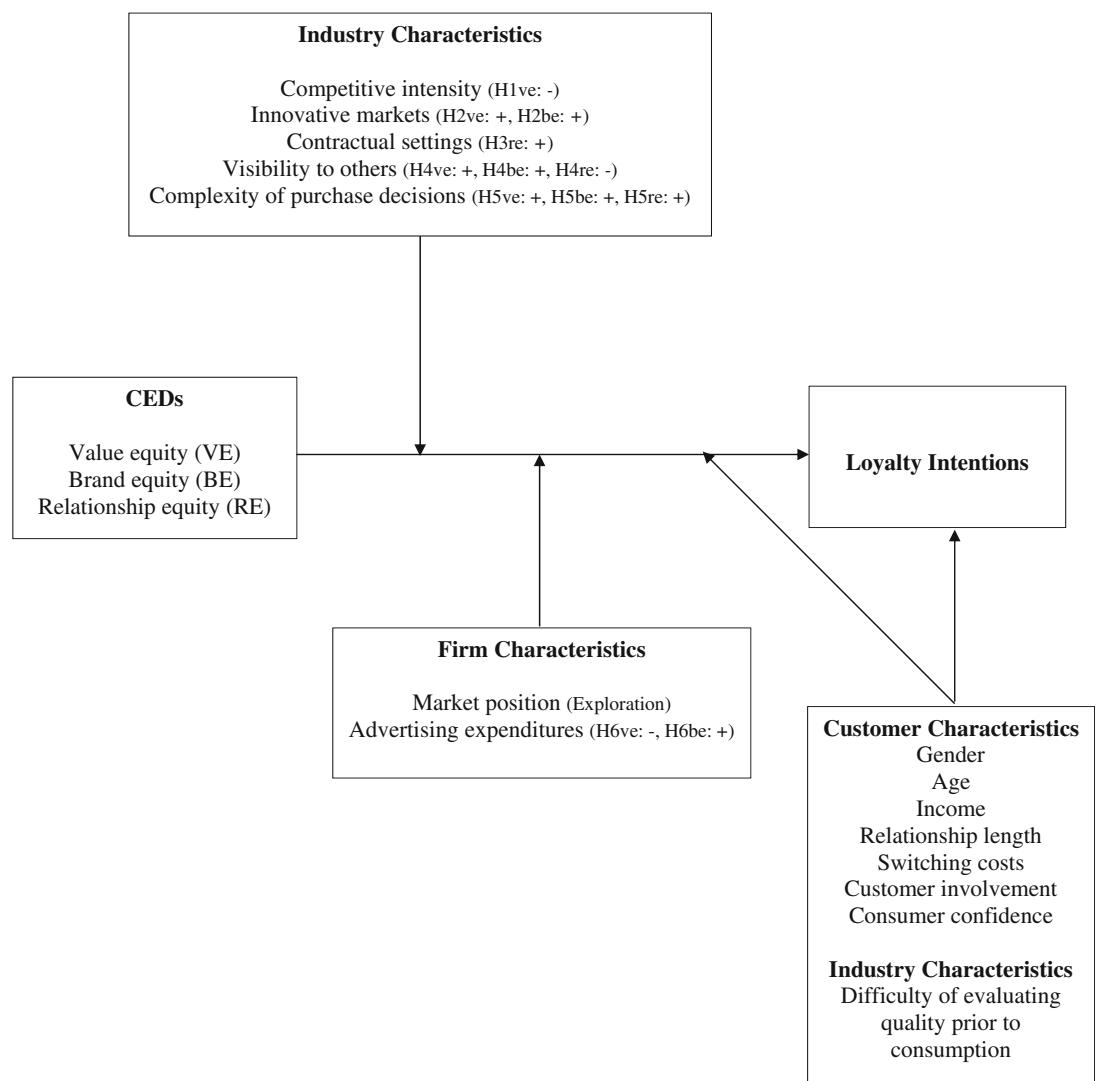

competitors intensively react to and imitate each other's marketing strategies (Gatignon 1984), implying that the strength of $\mathrm{BE}$ and RE as differentiators could decrease.

Similarly, while there is sufficient evidence of the moderating impact of innovative markets on the effects of VE and $\mathrm{BE}$, we do not know how innovative markets moderate the effect of RE on loyalty intentions. On the one hand, the effect of RE might be strengthened in innovative markets. Customers perceiving high RE are likely to trust firms, which decreases customer uncertainty of the goods/ services performance in innovative markets (Palmatier et al. 2009). On the other hand, the effect of RE might be weakened in innovative markets. Customers in innovative markets constantly search for new services and tend to pay more attention to value rather than their relationships with the firm (De Luca and Atuahene-Gima 2007). In addition, regarding contractual settings, in their framework, Rust et al. (2000) mention its moderating impact only on RE, not on $\mathrm{VE}$ or BE.

\section{Industry characteristics}

Competitive intensity Competition is usually more intense in industries with homogeneous rather than heterogeneous goods/services (Menguc and Auh 2006). When the offerings of goods/services are virtually the same, VE is difficult to build and becomes the basic requirement of all firms operating in competitive industries (Reimann et al. 2010; Rust et al. 2000). As a result, firms may be less likely to benefit from implementing VE because the perceived differences in VE are so tiny that customers can hardly use VE to differentiate between firms. Customers thus may pay less attention to VE when they make loyalty decisions, implying that the effect of VE is weaker in competitive industries (e.g., Seiders et al. 2005). We thus formulate the following hypothesis for VE:

H1ve: The relationship between VE and loyalty intentions is weaker in more competitive industries than in less competitive industries.

Innovative markets Innovative markets tend to have more new ideas, a higher level of innovative activities, and a larger amount of R\&D expenditures than do less innovative markets (Pleatsikas and Teece 2001). As a consequence, firms in innovative markets frequently introduce new goods/services to the market (Pleatsikas and Teece 2001) to improve customers' lives through better quality, usefulness, and ease (e.g., Hauser et al. 2006) — all components of VE. Customers in innovative markets thus expect better value from new goods/ services, implying that $\mathrm{VE}$ is a critical criterion in particular for these customers in their decisions to purchase new goods/ 
services. As such, we expect that VE is more important for customers in innovative markets.

Regarding BE, customers perceive uncertainty and risks in purchasing new goods/services (Littler and Melanthiou 2006). For example, customers are uncertain about information regarding new goods/services and choosing among alternatives (Urbany et al. 1989). BE thus might be more important in innovative markets. Erdem and Swait (1998) indicate that $\mathrm{BE}$, such as strong and innovative brands, functions as a credibility signal, reducing information search costs and perceived risks in innovative markets. Together, we expect that VE and $\mathrm{BE}$ are more important for customers in innovative markets.

$\mathrm{H} 2$ ve: The relationship between VE and loyalty intentions is stronger in more innovative markets than in less innovative markets.

H2be: The relationship between $\mathrm{BE}$ and loyalty intentions is stronger in more innovative markets than in less innovative markets.

Contractual settings In the CRM literature, the distinction between contractual and non-contractual settings is deemed important because customers may behave differently if they are contractually bound to a specific firm (Fader and Hardie 2007). In a contractual setting, customers and firms have an agreement on terms and conditions stated in the contract and the agreement is valid for a period of time (Gulati 1995). Customers in contractual settings tend to be locked in during the contractual period, but customers in non-contractual settings have the freedom to buy goods/services simultaneously from multiple firms (Burnham et al. 2003; Wirtz et al. 2014).

Because of the assumed behavioral difference between contractual and non-contractual settings, in accordance with Rust et al. (2000), we expect that RE is a more important strategy for firms in contractual than in non-contractual settings. RE is a way to "glue" customers to the firm. Contractual relationships lock customers in, providing the firm with more opportunities to glue existing customers to the firm because the firm has a direct connection with customers and thus knows exactly who they are and can collect more information about them. For example, firms may provide specific and personalized offerings (e.g., loyalty programs, affinity programs, special recognition and treatment, community-building programs, knowledge-building programs). Customers thus perceive the uniqueness of RE provided by contractual firms, which helps firms create unique relationships with customers (Bowen and Jones 1986) and increases customer attachment/commitment to postpone the termination of the contract (Rust et al. 2000). Evidence indicates that specific relationship constructs, such as commitment, have an effect on loyalty, particularly in contractual settings (e.g., Verhoef 2003). Compared with contractual settings, firms in non-contractual settings face more problems in identifying customers and collecting sufficient information about them. Consequently, these relationship-building strategies are less effective in non-contractual settings (e.g., Dowling and Uncles 1997). In summary, we expect that RE is a stronger strategy to enhance loyalty intentions in contractual than noncontractual settings.

H3re: The relationship between RE and loyalty intentions is stronger in contractual than in non-contractual settings.

Visibility to others Visibility to others is the extent to which others notice customers' use of goods/services (Fisher and Price 1992). Social comparison cue theory proposes that when people notice social comparison cues (e.g., visible goods/services), their public self-consciousness tends to be high, and thus they are concerned about what others think of them (Bearden and Rose 1990; Fisher and Price 1992). If so, customers are likely to pay more attention to publicly noticeable attributes/elements of visible goods/services, as other people's perceptions of what one uses or buys is important in this context. This indicates that if CEDs are perceived as being publicly noticeable, they should become more important for customers and, thus, for their loyalty intentions.

Specifically, VE is customers' objective assessments of the value of goods/services (Rust et al. 2000). The Oxford Learner's Dictionary defines objectivity as "the fact of not being influenced by personal feelings or opinions but consider only facts that can be proved," which implies that VE tends to be assessed by facts presented (e.g., quality and prices of the goods/services). This indicates that the value of goods/ services is commonly shared, meaning that the majority of other customers can easily recognize the value; as such, VE tends to be publicly noticeable. Consequently, the notion of public recognition implies that customers may pay more attention to $\mathrm{VE}$ in visible goods/services.

$\mathrm{BE}$ is even more publicly noticeable than VE, acting as a symbol of social status and identity (Rust et al. 2000). To maintain or indicate their perceived status and identity, customers are concerned about how others think of which brand they use or buy. As a result, customers tend to consider BE more relevant in decision making when the usage of goods/services is more visible (Fischer et al. 2010; Rust et al. 2000). This behavior is rooted in the need to make a good impression (Bearden and Rose 1990) and to be accepted by desired reference groups (Bearden and Etzel 1982).

Finally, RE is less likely to be publicly noticeable than VE and $\mathrm{BE}$ because the interaction between customers and the firm is embedded in customers' minds (Aurier and N'Goala 2010). For example, some stores warmly greet customers or actively provide help from frontline staff as tools for building customer relationships. Loyalty programs are also a popular 
customer relationship tool, providing customers useful customized coupons or special offers. The interactions with the frontline staff in the stores are meant to improve customer attachment; the offers provided by the loyalty program are meant to inform customers that stores understand their needs. Customer attachment or knowledge of needs is likely to be experienced and recognized by customers themselves only, as neither aspect can be easily observed by many other customers and thus is less likely to be used for social comparison purposes. Thus, we expect the following:

H4ve: The relationship between VE and loyalty intentions is stronger for visible than for less visible services.

H4be: The relationship between BE and loyalty intentions is stronger for visible than for less visible services.

H4re: The relationship between RE and loyalty intentions is weaker for visible than for less visible services.

Complexity of purchase decisions The complexity of purchase decisions is characterized by an ongoing and motivated cognitive process in which multiple important sources of information are integrated to produce an outcome (Wood and Bandura 1989). That is, customers undergo a more elaborate decision process, which may lead them to evaluate the "whole package" of the offering more intensively. If so, we expect that all three CEDs are crucial for customers in the context of purchase decision complexity, as CEDs are relevant to most of the important firm characteristics perceived by customers and may help customers reduce the complexity of purchase decisions (Rust et al. 2004; Vogel et al. 2008).

Specifically, Rust et al. (2000) propose that VE is more important for customers when purchase decisions are complex, as customers tend to evaluate the components (i.e., price, quality, and convenience) of VE carefully to derive the most utility. Regarding BE, customers encountering complex purchase decisions spend more time in collecting information to decrease risks of the future performance of goods/services (Wood and Bandura 1989). BE provides signal credibility, which may help customers reduce the complexity of purchase decisions, as credibility decreases search costs and also guarantees the quality of goods/ services (e.g., Erdem et al. 2006). Last, RE creates trust in firms (Rust et al. 2000), which strengthens customers' beliefs in firms' beneficent behavior in the future (Aurier and N'Goala 2010) and thus may also increase the importance of RE in complex purchase decisions. Thus, we formulate the following hypotheses:

H5ve: The relationship between VE and loyalty intentions is stronger for complex purchase decisions than for less complex purchase decisions.
H5be: The relationship between $\mathrm{BE}$ and loyalty intentions is stronger for complex purchase decisions than for less complex purchase decisions.

H5re: The relationship between RE and loyalty intentions is stronger for complex purchase decisions than for less complex purchase decisions.

\section{Firm characteristics}

Market position We use the term market position to examine how market leaders and followers differ in terms of the effectiveness of CEDs on loyalty intentions. Market leaders outsell market followers and have the largest percentage of market share in the corresponding industries (Hoeffler and Keller 2003). We empirically explore the moderation effect of market position, rather than formulating hypotheses, as double jeopardy theory (e.g., Ehrenberg et al. 1990) and information accessibility theory (Feldman and Lynch 1988; Knapp et al. 2014) propose opposite moderation effects of market position. The former proposes that CEDs are less important for market leaders, and the latter proposes that they are more important.

Specifically, in the customer loyalty literature, research has discussed the link between market share and customer loyalty (e.g., Ehrenberg et al. 1990). Researchers have empirically demonstrated the existence of the double jeopardy phenomenon: The key idea is that market leaders (market followers) have more (fewer) buyers who are also more (less) loyal (Ehrenberg et al. 1990). One implication of this empirical regularity is that market leaders should put low expectations on their marketing programs' ability to influence loyalty intentions because their customers already have strong loyalty intentions. In other words, market leaders are more likely to encounter the ceiling effect than market followers when investing in marketing strategies. As a result, double jeopardy theory proposes that the CEDs-loyalty link becomes weaker for market leaders.

In contrast, information accessibility theory proposes that the CEDs-loyalty link is stronger for market leaders than for market followers. This theory argues that the ability to access information is crucial for customers as input to judgment and decisions (Feldman and Lynch 1988; Knapp et al. 2014). One advantage of being a market leader is that customers tend to have more knowledge of market leaders than followers (Hoeffler and Keller 2003). More knowledge increases information accessibility, and thus customers have better encoding ability to retrieve relevant firms' information (Keller 1993). Moreover, knowledge increases customers' confidence in evaluating goods/services and willingness to translate retrieved information into decision making (Park et al. 2010).

Advertising expenditures "Advertising" here refers to nonprice advertising, which excludes price discounts (Kaul and 
Wittink 1995). We expect that for heavy advertisers, VE becomes weaker while BE becomes stronger. In terms of VE, market power theory (Mitra and Lynch 1995) suggests that advertising decreases price sensitivity because advertising creates differentiation, which enables firms to charge higher prices (Kaul and Wittink 1995). Because price is one component of VE, this theory implies that customers who are exposed to more advertising become less sensitive to perceived VE and thus are less likely to translate perceived VE into loyalty intentions. Consequently, firms with intensive expenditures may experience a weakened effect of VE.

In terms of BE, non-price advertising aims to establish high brand familiarity (Kaul and Wittink 1995), an extrinsic cue that signals brands (Pieters and Wedel 2004). Mere exposure theory proposes that customers form brand preferences partly from familiarity triggered by advertising, which implies that the more customers are exposed to advertising, the more familiar they are with brands, and the more likely they are to consider those brands in their decision making (McAlister et al. 2007). Brand preferences may be even more salient for firms with intensive advertising expenditures, as these firms provide a sufficient number of exposures to enhance the wear-in effect of advertising (Vakratsas and Ambler 1999). Thus, we assume that the effect of BE is strengthened for firms with intensive advertising expenditures.

We do not expect advertising to have a moderating effect on the RE-loyalty link, because RE is mainly built over time when customers interact with firms through loyalty programs, special recognition and treatment programs, affinity programs, and community programs (Rust et al. 2000). Such programs are strategies of customer relationship management and usually distinct from the functions of advertising. In summary, we only hypothesize the moderating effect of advertising expenditures on the VE-loyalty and BE-loyalty links:

H6ve: The relationship between VE and loyalty intentions is weaker for firms with higher advertising expenditures than for firms with lower advertising expenditures.

H6be: The relationship between BE and loyalty intentions is stronger for firms with higher advertising expenditures than for firms with lower advertising expenditures.

\section{Research design}

\section{Data}

To examine the heterogeneity of the effects of CEDs on loyalty intentions at the industry and firm level, we used three types of data sources. The first data source is part of a large- scale measurement of customer performance in the Netherlands. The data include 8924 customer responses of 95 leading companies across 18 services industries (i.e., insurance, health insurance, banking, mobile phone, landline phone, energy providers, gasoline providers, travel agencies, holiday resorts, airlines, supermarkets, health/beauty retailing, department stores, electronic retailing, do-it-yourself retailing, furnishing retailing, e-booking, and online retailing). For each industry, the survey provides respondents with a list of firms (between four and 11). Respondents can choose the companies (maximum of three) they are currently a customer of and then repeatedly answer questions about the chosen firms. The sample size per industry was between 303 and 781 customers, with men comprising $46.4 \%$ of our collective sample. In terms of age, $22.9 \%$ of the respondents were between the ages of 18 and 29 years, $24.8 \%$ were between 30 and 39 years, $20.1 \%$ were between 40 and 49 years, $25.3 \%$ were between 50 and 64 years, and $7.0 \%$ were more than 65 years. In terms of household income, $48.9 \%$ of respondents fell into the category of $€ 30,000$ to $€ 60,000$ per year.

The second data source is an expert survey in which 88 respondents (managers and business consultants) gave 178 responses regarding their opinions on the studied industry characteristics. One respondent could provide multiple responses to different industries. The managers came from the leading firms of multiple industries in the Netherlands (e.g., Aegon, ING bank, KPN, Wehkamp, Ziggo). The business consultants included principals, consultants, and business analysts from leading consultancies in the Netherlands (e.g., BCG, Deloitte, Ernst \& Young, McKinsey). We e-mailed 2000 questionnaires to the experts and informed them that we would donate $€ 2$ to the charity organizations of their choice upon completion of one questionnaire. As a result, 88 experts provided 185 responses, seven of which were incomplete. Therefore, the complete responses are 178, for a response rate of $4.4 \%$. We provide additional information of the expert survey in Web Appendix B. The third data source consists of external sources, including data from ACNielsen on firms' annual advertising expenditures and from firms' annual revenue reports.

\section{Measurement of variables}

Measurement of loyalty intentions Following Rust et al. (2004), we measured loyalty intentions with self-reported probabilities of repurchasing. The respondents allocated 100 points over the firms of each industry, which allowed us to measure the loyalty shares among competitors in each industry. For example, suppose that a respondent is interested in three supermarkets. For his or her next purchase, he or she allocates 100 points over these three supermarkets, for example, 40,30 , and 30 . These numbers indicate the probabilities of his or her next visit to these 
supermarkets - that is, $40 \%$ of the probability to visit the first supermarket but only $30 \%$ to visit the last two supermarkets. This measurement of loyalty intentions reflects the increasing polygamous loyalty in customer behavior nowadays (Cooil et al. 2007). The range of loyalty intentions was between 0 and 100 .

Measurement of CEDs To measure CEDs, we used sevenpoint Likert scales (1 = "totally disagree"; 7 = "totally agree") with multiple items. Web Appendix C provides an overview of the history of developing measures for CEDs. We limited the number of items to increase response rates, as respondent fatigue and lack of time are the main reasons for low response rates (Bergkvist and Rossiter 2007; Böckenholt and Lehmann 2015). VE focuses on the price-quality ratio and convenience (Rust et al. 2004; Verhoef et al. 2007); BE measures the brand's perceived strength and innovative abilities (Verhoef et al. 2007); and RE consists of items focusing on knowing customers' needs, feeling at home, and feeling commitment (Verhoef 2003; Verhoef et al. 2007). The principal component analysis (PCA) indicates that the included measures of CEDs ended up in the expected factors (see Web Appendix D). Using Cronbach's $\alpha$, we found that the items for VE, BE, and RE are sufficiently reliable, with values of $.73, .70$, and .85 , respectively (see Table 3 ). We used the averages of the items of VE, BE, and RE in the data analysis for interpretation purposes of the interaction effects. We used grand-meancentered CEDs, instead of group-mean-centered CEDs. Grand-mean-centered CEDs refer to the means obtained from all responses of the 18 industries. Group-mean-centered CEDs refer to the means obtained from respondents of each industry. The reason for using grand-mean-centered CEDs is that multi-level modeling estimates the mean and variance of the parameter values from all industries and firms, rather than estimating parameter values for each firm and each industry (Hox 2002). ${ }^{4}$

To examine discriminant validity, we calculated the average variance extracted (AVE) of each CED as well as each CED's shared variance with other CEDs (Fornell and Larcker 1981). The AVE is .65 for VE, .77 for BE, and .77 for RE; the shared variance is .33 for $\mathrm{VE}$ and $\mathrm{BE}, .30$ for $\mathrm{VE}$ and $\mathrm{RE}$, and .36 for BE and RE. These results show that the AVE of the CEDs is larger than the shared variance, confirming discriminant validity. To test for potential common method bias

\footnotetext{
${ }^{4}$ To examine measurement invariance of $\mathrm{VE}, \mathrm{BE}$, and RE, we used structural equation modeling by comparing every two industries from 18 industries, which resulted in 153 comparisons. We randomly chose 17 comparisons (approximately $10 \%$ of 153 ) and found that our data do not meet measurement invariance. To account for measurement noninvariance (i.e., cross-industry differences in parameters), Davidov et al. (2012) propose including relevant contextual variables. We thus included five industry characteristics and also two firm characteristics as control variables in the model.
}

(CMB), we used two methods: (1) partial correlation with a marker variable (Lindell and Whitney 2001) and (2) common method factor based on the process in Liang et al. (2007). For the first method, Lindell and Whitney (2001) indicate that a marker variable is hardly relevant to the dependent variable. Following Verhoef and Leeflang (2009), we used consumer confidence as a marker variable. We also used customers' age as a marker variable because several empirical studies (e.g., Bell et al. 2005; Mägi 2003) indicate that age does not have a significant effect on customer loyalty. By using these two marker variables, we found that the correlation change of indicators and loyalty intentions is small, approximately $1 \%$, after controlling for consumer confidence or age. The second method showed that the substantive factor loading explains 53 and $43 \%$ of the variance of the indicators before and after including the method factor, respectively. The method factor explained $23 \%$ of the variance. The results of the two methods indicate that $\mathrm{CMB}$ exists in our data, but is not likely a serious concern. $^{5}$

Control variables At the customer level, following $\mathrm{Ou}$ et al. (2014), we included theoretically argued variables influencing loyalty intentions: gender, age, income, relationship length, ${ }^{6}$ involvement, switching costs, and consumer confidence. At the industry level, we included difficulty of evaluating quality prior to consumption as a control variable, because Fischer et al. (2010) empirically find that this variable strengthens the relevance of brands in decision making.

Industry characteristics We collected industry characteristics mainly from the expert survey, except in the case of contractual settings. $\operatorname{ICC}(2)$ indicates that the average agreement rate of experts on industry characteristics was .67 across 18 industries. We employed seven-point Likert scales to assess these characteristics; the relevant questions appear in Web Appendix D. We used PCA to examine whether these industry characteristics are unidimensional, as industry characteristics may theoretically correlate with each other and cause estimation problems due to multicollinearity (e.g., Evans 1991). For innovative

\footnotetext{
${ }^{5}$ The result of the explained variance $(23 \%)$ shows that $\mathrm{CMB}$ exists but is likely not a concern. Because our respondents are customers from different firms and different industries, we assume that the explained variance of CMB comes not only from respondents (i.e., response format) but also from different contexts (Podsakoff et al. 2003). To account for the potential CMB from different contexts, we included five industry and two firm characteristics as control variables.

${ }^{6}$ Of the respondents, $30.6 \%$ did not give information about income and $8.7 \%$ did not know the relationship length. When analyzing the multilevel model, we used (1) the most frequently mentioned value and (2) multiple imputation to replace these missing values. Both methods gave similar results. Therefore, we chose the first method to analyze Eq. 1, which we elaborated in the subsequent section.
} 
Table 3 Descriptive statistics and correlation matrix

\begin{tabular}{|c|c|c|c|c|c|c|c|c|c|c|c|c|c|c|}
\hline Main variables & M & SD & $\begin{array}{l}\text { Sample } \\
\text { size }\end{array}$ & 1 & 2 & 3 & 4 & 5 & 6 & 7 & 8 & 9 & 10 & 11 \\
\hline Loyalty intentions & 42.81 & 29.76 & 8924 & $.30 * *$ & $.34 * *$ & $.39 * *$ & $.13^{* *}$ & .003 & .01 & -.01 & $.06 * *$ & $-.08 * *$ & $.11 * *$ & $.14^{* *}$ \\
\hline 1. VE & 4.98 & 1.09 & 8924 & $.73^{\mathrm{c}}$ & $.58^{* *}$ & $.55^{* *}$ & $.03 * *$ & $-.04 * *$ & $.13 * *$ & -.01 & $.09 * *$ & $.10 * *$ & $-.08 * *$ & $-.17 * *$ \\
\hline 2. $\mathrm{BE}$ & 4.75 & 1.09 & 8924 & & .70 & $.60 * *$ & $.11 * *$ & $-.07 * *$ & $.03 * *$ & $-.02^{+}$ & $.08 * *$ & $.04 * *$ & -.01 & $-.03 * *$ \\
\hline 3. $\mathrm{RE}$ & 4.11 & 1.24 & 8924 & & & .85 & $.04 * *$ & -.02 & $.04 * *$ & $-.04 * *$ & $.07 * *$ & $.05 * *$ & $-.02 *$ & $-.06^{* *}$ \\
\hline 4. Advertising expenditures & $0.2^{\mathrm{a}}$ & 0.16 & $94^{\mathrm{d}}$ & & & & n.a. & $-.20 * *$ & $-.07 * *$ & $-.06^{* *}$ & $.07 * *$ & $.21 * *$ & $-.11 * *$ & $-.13^{* *}$ \\
\hline 5. Market position & n.a. & n.a. & $75^{\mathrm{b}, \mathrm{d}}$ & & & & & n.a. & $.13^{* *}$ & $.23 * *$ & $-.26 * *$ & $-.07 * *$ & $-.03 * *$ & $.04 * *$ \\
\hline 6. Competitive intensity & 5.59 & 0.74 & 18 & & & & & & .89 & $.44 * *$ & $.03 * *$ & $.06^{* *}$ & $-.28 * *$ & $-.20 * *$ \\
\hline 7. Innovative markets & 3.86 & 0.72 & 18 & & & & & & & .85 & $-.14 * *$ & $-.26^{* *}$ & -.01 & $-.08 * *$ \\
\hline $\begin{array}{l}\text { 8. Complexity of purchase } \\
\text { decisions }\end{array}$ & 4.38 & 0.9 & 18 & & & & & & & & .87 & $.30 * *$ & $-.20 * *$ & $-.13^{* *}$ \\
\hline 9. Visibility to others & 3.63 & 1.10 & 18 & & & & & & & & & .94 & $-.30 * *$ & $-.59 * *$ \\
\hline $\begin{array}{l}\text { 10. Difficulty of evaluating } \\
\text { quality }\end{array}$ & 4.43 & 0.63 & 18 & & & & & & & & & & .77 & $.31 * *$ \\
\hline 11. Contractual settings & n.a. & n.a. & 18 & & & & & & & & & & & n.a. \\
\hline
\end{tabular}

n.a. not applicable

$* * P<.01 ; * p<.05 ;+p<.1$

${ }^{a}$ This is the number of the share of firms' advertising expenditures = (advertising expenditures of firm i)/(total amount of advertising expenditures of the firms in one industry)

${ }^{\mathrm{b}}$ An ordinal variable. There is no available revenue information for 20 firms in the data

${ }^{c}$ The value of this diagonal is the Cronbach's $\alpha$

${ }^{\mathrm{d}}$ For data analysis, we created two variables representing the missing value for advertising expenditures and market position (e.g., $1=$ missing value; $0=$ no missing value). We included these two variables in Eq. 1 to retain the same sample size. The dummy variables serve as adjustments for missing values

markets, we originally used eight measures. Three measures ended up with multiple factors, and thus we excluded them. Web Appendix D shows that the five industry characteristics ended up in the expected separate components. The reliability (Cronbach's $\alpha$ ) for the items related to industry characteristics is sufficient, with values between .77 and .94 (see Table 3). For each industry, we averaged the factor scores of each expert's opinions on the corresponding industry characteristics and employed this information in our data analysis. Finally, with the definition of contractual settings mentioned previously (Fader and Hardie 2007), we coded contractual settings as 1 and noncontractual settings as 0 .

Firm characteristics We collected firm characteristics from external sources and ACNielsen. We measured firms' market position by their revenue ranking in the correspondent industries. We collected revenue information from firms' annual reports. We then coded the market position by the ascending sequence of firms' revenues. Namely, we coded firms with the highest revenues in the corresponding industries as 1 and considered them the market leader. We coded the remaining firms, which we considered market followers, in an ascending sequence (i.e., 2, 3, 4, and so on). In addition, ACNielsen provides firms' annual expenditures in non-price advertising activities. Because we are interested in the relative advertising expenditures between competitors in an industry, we divided each firm's advertising expenditures by the total amount of advertising expenditures in the corresponding industry.

\section{Model specification}

We estimated a multi-level model with four levels to test the conceptual model, as the original data are hierarchical with four levels: customer responses (first level), customers (second level), firms (third level), and industries (fourth level). We expect that the first level (customer responses) is less straightforward than the other three, and thus we explain why its inclusion is necessary. Some respondents in our data repeatedly gave responses to multiple firms if they are currently a customer of these firms. Not including this level would produce correlated errors within customers and lead to inconsistent estimates. This is similar to the idea of repeated measures in the multilevel model (e.g., Hox 2002). We use $e_{i j m n}$ in Eq. 2 to account for the correlated errors within respondents. 
We used a generalized linear model (GLM) ${ }^{7}$ because it does not need to meet the assumptions of normally distributed dependent variables or the homoscedastic variance of errors required in standard regression models. We used one of the GLMs, family(binomial) and link(logit). The family(binomial) refers to a binomial distribution of the dependent variable. Proportions are assumed to have a binomial distribution (Baum 2008; Moore and McCabe 2003). Our dependent variable, loyalty intentions, is proportional because the variable measures self-reported probabilities of repurchasing with multiple firms. The link(logit) refers to a logit transformation of the dependent variable, which assumes a linear relationship between this dependent variable and its predictors. We specify our model as follows:

$\mathrm{LI}_{\mathrm{ijmn}}=\operatorname{logit}\left(\mathrm{U}_{\mathrm{ijmn}}\right)$.

Level one

$\mathrm{U}_{\mathrm{ijmn}}=\pi_{0 \mathrm{jmn}}+\mathrm{e}_{\mathrm{ijmn}}$.

Level two

$$
\begin{aligned}
\pi_{0 \mathrm{jmn}}= & \beta_{0 \mathrm{mn}}+\beta_{1 \mathrm{mn}} \mathrm{VE}_{\mathrm{jmn}}+\beta_{2 \mathrm{mn}} \mathrm{BE}_{\mathrm{jmn}} \\
& +\beta_{3 \mathrm{mn}} \mathrm{RE}_{\mathrm{jmn}}+\beta_{4 \mathrm{mn}} \mathrm{CV}_{\mathrm{jmn}}+\eta_{\mathrm{jmn}} .
\end{aligned}
$$

Level three

$$
\begin{aligned}
& \beta_{0 \mathrm{mn}}=\gamma_{00 \mathrm{n}}+\gamma_{010} \mathrm{FV}_{0 \mathrm{mn}}+\mu_{0 \mathrm{mn}} ; \\
& \beta_{1 \mathrm{mn}}=\gamma_{10 \mathrm{n}}+\gamma_{110} \mathrm{FV}_{0 \mathrm{mn}}+\mu_{1 \mathrm{mn}} ; \\
& \beta_{2 \mathrm{mn}}=\gamma_{20 \mathrm{n}}+\gamma_{210} \mathrm{FV}_{0 \mathrm{mn}}+\mu_{2 \mathrm{mn}} ;
\end{aligned}
$$

and

$$
\beta_{3 \mathrm{mn}}=\gamma_{30 \mathrm{n}}+\gamma_{310} \mathrm{FV}_{0 \mathrm{mn}}+\mu_{3 \mathrm{mn}} .
$$

Level four

$\gamma_{00 \mathrm{n}}=\alpha_{000}+\alpha_{001} \mathrm{IV}_{00 \mathrm{n}}+\nu_{00 \mathrm{n}}$

$\gamma_{10 \mathrm{n}}=\alpha_{100}+\alpha_{101} \mathrm{IV}_{00 \mathrm{n}}+\nu_{10 \mathrm{n}}$

$\gamma_{20 \mathrm{n}}=\alpha_{200}+\alpha_{201} \mathrm{IV}_{00 \mathrm{n}}+\nu_{20 \mathrm{n}}$

and

$$
\gamma_{30 \mathrm{n}}=\alpha_{300}+\alpha_{301} \mathrm{IV}_{00 \mathrm{n}}+\nu_{30 \mathrm{n}}
$$

\footnotetext{
${ }^{7}$ Web Appendix E presents the tests of these assumptions. We used the gllamm in Stata 12 for the GLM model.
}

where

$\mathrm{LI}_{\mathrm{ijmn}}$

loyalty intentions for firm $m$ evaluated by customer $j$ in industry $n$, where $i$ denotes the number of firms in industry $n$ that customer $j$ evaluates

$\operatorname{logit}\left(\mathrm{U}_{\mathrm{ijmn}}\right)$ the logit link function transforming loyalty intentions into values on a logit scale ranging from $-\infty$ to $\infty$ (i.e., $\mathrm{U}_{\mathrm{ijmn}}$ )

$\mathrm{VE}_{\mathrm{jmn}} \quad$ VE for firm $m$ evaluated by customer $j$ in industry $n$

$\mathrm{BE}_{\mathrm{jmn}} \quad \mathrm{BE}$ for firm $m$ evaluated by customer $j$ in industry $n$

$\mathrm{RE}_{\mathrm{jmn}} \quad \mathrm{RE}$ for firm $m$ evaluated by customer $j$ in industry $n$

$\mathrm{CV}_{\mathrm{jmn}}$ customer-level control variables - a row vector of gender, age, income, relationship length, switching costs, involvement, and consumer confidence

$\mathrm{FV}_{0 \mathrm{mn}} \quad$ firm characteristics - $\mathrm{a}$ row vector of market position and advertising expenditures

$\mathrm{IV}_{00 \mathrm{n}} \quad$ industry characteristics - a row vector of competitive intensity, innovative markets, contractual settings, visibility to others, complexity of purchase decisions, and difficulty of evaluating quality prior to consumption (as a control) level-one residuals (repeated level) level-two residuals (customer level) level-three residuals (firm level), $y=0,1,2,3$; and

level-four residuals (industry level), $z=0,1$, $2,3$.

In addition, $\pi_{0 \mathrm{jmn}}$ is the random level-one intercept; $\beta_{0 \mathrm{mn}}$ is the level-two intercept; $\beta_{1 \mathrm{mn}}, \beta_{2 \mathrm{mn}}$, and $\beta_{3 \mathrm{mn}}$ are the effects of $\mathrm{VE}, \mathrm{BE}$, and RE, respectively; $\beta_{4 \mathrm{mn}}$ is a vector of coefficients corresponding to customer-level control variables; $\gamma_{00 \mathrm{n}}, \gamma_{10 \mathrm{n}}$, $\gamma_{20 \mathrm{n}}$, and $\gamma_{30 \mathrm{n}}$ are level-three intercepts; $\gamma_{010}$ is a vector of the effects of firm characteristics on loyalty intentions; $\gamma_{110}, \gamma_{210}$, and $\gamma_{310}$ are a vector of coefficients for the interaction terms at the firm level; $\alpha_{000}, \alpha_{100}, \alpha_{200}$, and $\alpha_{300}$ are level-four intercepts; $\alpha_{001}$ is a vector of the effects of industry characteristics on loyalty intentions; $\alpha_{101}, \alpha_{201}$, and $\alpha_{301}$ are a vector of coefficients for the interaction terms at the industry level.

\section{Empirical results}

\section{Model fit}

Table 4 contains the parameter estimates of three different multi-level models. We mean-centered all the variables in 
Table 4 Multi-level model results for loyalty intentions

\begin{tabular}{|c|c|c|c|c|c|c|}
\hline & \multicolumn{2}{|c|}{ Model 1} & \multicolumn{2}{|c|}{ Model 2} & \multicolumn{2}{|c|}{ Model 3} \\
\hline & Coeff. & S.E. & Coeff. & S.E. & Coeff. & \\
\hline VE & $1.86^{* *}$ & .14 & $1.84 * *$ & .19 & $1.95^{* *}$ & .20 \\
\hline $\mathrm{BE}$ & $.66^{* *}$ & .12 & $.49 * *$ & .14 & $.56^{* *}$ & .18 \\
\hline $\mathrm{RE}$ & $1.79 * *$ & .11 & $1.69 * *$ & .13 & $1.07 * *$ & .16 \\
\hline
\end{tabular}

Industry-level moderators

$\mathrm{VE} \times$ competitive intensity (H1ve: - )

$\mathrm{BE} \times$ competitive intensity (exploration)

$\mathrm{RE} \times$ competitive intensity (exploration)

$\mathrm{VE} \times$ innovative markets $($ H2ve: +$)$

$\mathrm{BE} \times$ innovative markets $(H 2 b e:+)$

$\mathrm{RE} \times$ innovative markets (exploration)

$\mathrm{VE} \times$ contractual settings (exploration)

$\mathrm{BE} \times$ contractual settings (exploration)

$\mathrm{RE} \times$ contractual settings (H3re: + )

$\mathrm{VE} \times$ visibility to others (H4ve: +$)$

$\mathrm{BE} \times$ visibility to others (H4be:+)

$\mathrm{RE} \times$ visibility to others (H4re: - )

$\mathrm{VE} \times$ complexity of purchase decisions (H5ve: + )

$\mathrm{BE} \times$ complexity of purchase decisions (H5be: +)

$\mathrm{RE} \times$ complexity of purchase decisions (H5re: +)

$\mathrm{VE} \times$ difficulty of evaluating quality prior to consumption (control)

$\mathrm{BE} \times$ difficulty of evaluating quality prior to consumption (control)

$\mathrm{RE} \times$ difficulty of evaluating quality prior to consumption (control)

Firm-level moderators

$\mathrm{VE} \times$ market position (exploration)

$\mathrm{BE} \times$ market position (exploration)

$\mathrm{RE} \times$ market position (exploration)

$\mathrm{VE} \times$ advertising expenditures (H6ve: - )

$\mathrm{BE} \times$ advertising expenditures (H6be: + )

$\mathrm{RE} \times$ advertising expenditures (exploration)

Customer-level moderators

$\mathrm{VE} \times$ female (1, vs. male: 0$)$

$\begin{array}{llll}-1.62 * * & .44 & -1.02 * * & .33\end{array}$

$\begin{array}{llll}.06 & .34 & .32 & .27\end{array}$

$\begin{array}{llll}.12 & .26 & -.10 & .25\end{array}$

$\begin{array}{llll}74 * * & .28 & .33 & .30\end{array}$

$\begin{array}{llll}.91 * * & .33 & .67 * & .28\end{array}$

$\begin{array}{llll}-.45 * & .23 & -.73 * * & .21\end{array}$

$\begin{array}{llll}.22 & .41 & .35 & .40\end{array}$

$\begin{array}{llll}.34 & .38 & .11 & .36\end{array}$

$\begin{array}{llll}.99 * * & .28 & .70 * & .31\end{array}$

$\begin{array}{llll}.80 * & .38 & 1.88 * * & .38\end{array}$

$\begin{array}{llll}.35 & .35 & -.34 & .36\end{array}$

$\begin{array}{llll}-1.45 * * & .31 & -1.57 * * & .31\end{array}$

$\begin{array}{llll}-.68 * * & .19 & -.40 * & .20\end{array}$

$\begin{array}{llll}.31+ & .18 & .44 * & .19\end{array}$

$\begin{array}{llll}.55 * * & .15 & -.08 & .17\end{array}$

$\begin{array}{llll}-.18 & .13 & .11 & .28\end{array}$

$\begin{array}{llll}.21 & .27 & .33 & .27\end{array}$

$\begin{array}{llll}-.92 * * & .22 & -.89 * * & .25\end{array}$

$\begin{array}{llll}.14+ & .08 & .12 & .08\end{array}$

$\begin{array}{llll}-.08 & .08 & .04 & .08\end{array}$

$\begin{array}{llll}.21 * * & .07 & .07 & .07\end{array}$

$\begin{array}{llll}-1.59 & 1.01 & -4.64 * * & .96\end{array}$

$\begin{array}{llll}.91 & 1.02 & 2.30 * & 1.05\end{array}$

$\begin{array}{llll}.59 & .90 & -1.59+ & .89\end{array}$

$\mathrm{VE} \times$ age

$\mathrm{VE} \times$ income

$\mathrm{VE} \times$ relationship length

$\mathrm{VE} \times$ switching costs

$\mathrm{VE} \times$ involvement

$\mathrm{VE} \times$ consumer confidence

$\mathrm{BE} \times$ female (1, vs. male: 0$)$

$\mathrm{BE} \times$ age

$\mathrm{BE} \times$ income

$\mathrm{BE} \times$ relationship length

$\mathrm{BE} \times$ switching costs

$\mathrm{BE} \times$ involvement

$\mathrm{BE} \times$ consumer confidence

$\mathrm{RE} \times$ female (1, vs. male: 0$)$

$\mathrm{RE} \times$ age

$\mathrm{RE} \times$ income
$.72 * \quad .28$

$.13 \quad .12$

$-.09 \quad .16$

$.20 * \quad .08$

$08 \quad .08$

$.01 \quad .10$

$-.78 * * \quad .15$

$\begin{array}{ll}-.23 & .26\end{array}$

$-.42 * * \quad .12$

$\begin{array}{ll}-.08 & .14\end{array}$

$\begin{array}{ll}.04 & .07\end{array}$

$\begin{array}{ll}-.05 & .07\end{array}$

$30 * * \quad .11$

$.12 \quad .14$

$1.37 * * \quad .25$

$.30 * * \quad .10$

$.59 * * \quad .12$ 
Table 4 (continued)

\begin{tabular}{|c|c|c|c|c|c|c|}
\hline \multirow[b]{2}{*}{$\begin{array}{l}\text { VE } \\
\text { BE } \\
\text { RE }\end{array}$} & \multicolumn{2}{|l|}{ Model 1} & \multicolumn{2}{|l|}{ Model 2} & \multicolumn{2}{|l|}{ Model 3} \\
\hline & $\begin{array}{l}\text { Coeff. } \\
1.86^{* *} \\
.66^{* *} \\
1.79^{* *}\end{array}$ & $\begin{array}{l}\text { S.E. } \\
.14 \\
.12 \\
.11\end{array}$ & $\begin{array}{l}\text { Coeff. } \\
1.84 * * \\
.49 * * \\
1.69 * *\end{array}$ & $\begin{array}{l}\text { S.E. } \\
.19 \\
.14 \\
.13\end{array}$ & $\begin{array}{l}\text { Coeff. } \\
1.95^{* *} \\
.56^{* *} \\
1.07 * *\end{array}$ & $\begin{array}{l}\text { S.E. } \\
.20 \\
.18 \\
.16\end{array}$ \\
\hline $\mathrm{RE} \times$ relationship length & & & & & $-.38 * *$ & .07 \\
\hline $\mathrm{RE} \times$ switching costs & & & & & -.05 & .06 \\
\hline $\mathrm{RE} \times$ involvement & & & & & -.08 & .09 \\
\hline $\mathrm{RE} \times$ consumer confidence & & & & & $-.24 *$ & .12 \\
\hline \multicolumn{7}{|l|}{ Customer-level drivers } \\
\hline Female (1, vs. male: 0$)$ & -.17 & .20 & -.07 & .20 & .40 & .26 \\
\hline Age & $.15+$ & .09 & .13 & .09 & .16 & .11 \\
\hline Income & -.05 & .11 & -.00 & .11 & .17 & .14 \\
\hline Relationship length (RL) & $.14 *$ & .06 & .07 & .06 & .02 & .08 \\
\hline Switching costs (SC) & $-.22 * *$ & .07 & -.08 & .07 & $-.13+$ & .07 \\
\hline Involvement & $-.61 * *$ & .08 & $-.50 * *$ & .09 & $-.37 * *$ & .11 \\
\hline Consumer confidence (CC) & $-.45 * *$ & .12 & $-.34 * * *$ & .13 & $-.89 * *$ & .17 \\
\hline \multicolumn{7}{|l|}{ Industry-level drivers } \\
\hline Competition intensity & $2.73 * *$ & .39 & $3.73 * *$ & .42 & $1.32 * *$ & .43 \\
\hline Innovative markets & $-2.61 * *$ & .26 & $-2.77 * *$ & .34 & $-1.37 * *$ & .31 \\
\hline Contractual settings & $-1.40 * *$ & .48 & -.67 & .55 & $-1.64 * *$ & .59 \\
\hline Visibility to others & -.53 & .36 & -.45 & .50 & .48 & .47 \\
\hline Complexity of purchase decisions & $1.53 * *$ & .17 & $1.78^{* *}$ & .23 & $1.67 * *$ & .25 \\
\hline $\begin{array}{l}\text { Difficulty of evaluating quality prior to } \\
\text { consumption }\end{array}$ & .25 & .43 & $-3.19 * *$ & .45 & $-1.94 * *$ & .60 \\
\hline \multicolumn{7}{|l|}{ Firm-level drivers } \\
\hline Market position & -.13 & .08 & $-.20 *$ & .08 & $-.55^{* *}$ & .09 \\
\hline Advertising expenditures & $3.65^{* *}$ & 1.0 & -.16 & 1.10 & $-3.43 * *$ & 1.22 \\
\hline Intercept & $13.10^{* *}$ & .60 & $10.92+$ & 5.96 & $23.34 * *$ & 1.02 \\
\hline Log-likelihood & -2757.04 & & -2684.76 & & -2631.04 & \\
\hline Akaike information criterion & 5552.08 & & 5455.52 & & 5390.08 & \\
\hline $\mathrm{R} 2$ & .26 & & .28 & & .28 & \\
\hline
\end{tabular}

$* * P<.01 ; * p<.05 ;+p<.1$

the model to derive interpretable coefficients (Hox 2002). Model 1 includes the main effects of CEDs, controlling for the industry-, firm-, and customer-level variables. To explain the variance of the effects of CEDs on loyalty intentions, Model 2 includes the industry- and firm-level moderators. Model 3 estimates the joint moderating effects of industry, firm, and customer characteristics. We focus on Model 3 when discussing the results of the moderating effects because it has the best model fit $(-2631.04$; Akaike information criterion $=5390.08)$ and is significantly better than Model $1\left(\chi^{2}=-2631.04-(-2757.04)=126\right.$, $d f=45, p<.01)$.

\section{Main effects of CEDs}

Consistent with previous research (Rust et al. 2004; Vogel et al. 2008), we found a positive link between CEDs and loyalty intentions $(\mathrm{VE}=1.95, p<.01 ; \mathrm{BE}=.56, p<.01$; $\mathrm{RE}=1.07, p<.01)$. This finding provides an additional empirical generalization of the positive CEDs-loyalty link across various industries and firms (see also Ou et al. 2014).

\section{Moderating effects of industry characteristics}

Competitive intensity As expected, competitive intensity had a significant, negative interaction with VE; that is, the effect of VE is weaker in competitive industries $(-1.02, p<.01)$. However, through exploration, we found that competitive intensity had no moderating impact on the effect of BE (.32, $p>.1)$ or RE $(-.10, p>.1)$. Thus, H1ve is supported.

Innovative markets As expected, we found a moderating effect of innovative markets on the BE-loyalty link. This link is strengthened in innovative markets $(.67, p<.05)$. However, 
we did not find a significant interaction between innovative markets and VE $(.33, p>.1)$. These results provide support for H2be but not for H2ve. Through exploration, we found that innovative markets decrease the effect of RE $(-.73, p<.01)$.

Contractual settings As expected, the effect of RE was stronger in contractual settings $(.70, p<.05)$, in support of H3re. However, our results indicate that contractual settings do not influence the effects of $\operatorname{VE}(.35, p>.1)$ and $\operatorname{BE}(.11, p>.1)$ on loyalty intentions.

Visibility to others As expected, when the usage of goods/ services is visible to others, the effect of VE is stronger (1.88, $p<.01)$, but the effect of $\operatorname{RE}(-1.57, p<.01)$ is weaker. Therefore, H4ve and H4re are supported. However, the results show no support for H4be, as we did not find a significant interaction between $\mathrm{BE}$ and visibility to others $(-.34, p>.1)$.

Complexity of purchase decisions We expected that the effects of CEDs would be stronger when customers encounter complexity in purchase decisions. In such cases, however, we found that the effect of VE decreases $(-.40, p<.05)$, while the effect of BE $(.44, p<.05)$ increases. The relationship between $\mathrm{RE}$ and loyalty intentions was not affected $(-.08, p>.1)$. Thus, H5be is supported, while H5ve and H5re are not supported.

\section{Moderating effects of firm characteristics}

Market position Double jeopardy theory and information accessibility theory expect market position to have opposing moderating effects on the CEDs-loyalty link. Through exploration, we did not find a moderating impact of firms' market position on the link between loyalty intentions and any of the three CEDs (VE: .12, $p>.1$; BE: .04, $p>.1$; RE: .07; $p>.1$ ).

Advertising expenditures We found that firms' advertising expenditures have a moderating impact on the effects of all three CEDs. As expected, the effect of VE $(-4.64, p<.01)$ is weaker, but the effect of $\mathrm{BE}(2.30, p<.05)$ is stronger for firms that invest heavily in advertising. Thus, H6ve and H6be are supported. We also found that the $\mathrm{RE} \times$ advertising interaction is marginally significant $(-1.59, p<.1)$.

\section{Explained variance of the effects of CEDs at the industry and firm level}

We calculated the extent to which the cross-industry and cross-firm variance of the effects of CEDs is explained by including five industry and two firm characteristics. Table 5 reports the results. Model 1 shows that the cross-industry variances of VE $(1.66, p<.01), \mathrm{BE}(1.48, p<.01)$, and RE $(2.45$, $p<.01)$ are significant. The cross-firm variances of VE $(1.21$, $p<.01), \mathrm{BE}(1.86, p<.01)$, and $\mathrm{RE}(1.34, p<.01)$ are also significant. The significant variance indicates that the effects of CEDs differ substantially across industries and firms. Therefore, it is important to explain why such a variance takes place. After we included industry and firm characteristics in Model 2, the cross-industry variance of CEDs decreases and becomes non- significant (.07 for VE, .39 for BE, and .53 for $\mathrm{RE} ; p>.1)$. The cross-firm variance of CEDs also decreases.
Table 5 (Explained) variance of the effects of CEDs across industries and firms

\begin{tabular}{|c|c|c|c|c|c|c|}
\hline & \multicolumn{2}{|c|}{ Model 1} & \multicolumn{2}{|c|}{ Model 2} & \multicolumn{2}{|c|}{ Model 3} \\
\hline & Coeff. & S.E. & Coeff. & S.E. & Coeff. & S.E \\
\hline \multicolumn{7}{|c|}{ (Explained) variance of CEDs effects across industries } \\
\hline VE & $1.66^{* *}$ & .43 & .07 & .30 & .02 & .29 \\
\hline Explained variance of VE effect ${ }^{\mathrm{a}}$ & & & $95.8 \%$ & & $98.7 \%$ & \\
\hline $\mathrm{BE}$ & $1.48^{* *}$ & .36 & .39 & .28 & .34 & .22 \\
\hline Explained variance of BE effect ${ }^{\mathrm{a}}$ & & & $73.6 \%$ & & $77.0 \%$ & \\
\hline $\mathrm{RE}$ & $2.45^{* *}$ & .49 & .53 & .43 & .19 & .15 \\
\hline Explained variance of $\mathrm{RE}$ effect $\mathrm{a}^{\mathrm{a}}$ & & & $78.4 \%$ & & $92.2 \%$ & \\
\hline \multicolumn{7}{|c|}{ (Explained) variance of CEDs effects across firms } \\
\hline $\mathrm{VE}$ & $1.21^{* *}$ & .46 & $.97 *$ & .47 & $.87^{+}$ & .51 \\
\hline Explained variance of VE effect ${ }^{\mathrm{a}}$ & & & $19.8 \%$ & & $28.1 \%$ & \\
\hline $\mathrm{BE}$ & $1.86^{* *}$ & .35 & .65 & .67 & .57 & .76 \\
\hline Explained variance of $\mathrm{BE}$ effect ${ }^{\mathrm{a}}$ & & & $65.1 \%$ & & $69.4 \%$ & \\
\hline $\mathrm{RE}$ & $1.34^{* *}$ & .36 & $1.29^{* *}$ & .34 & $1.13 * *$ & .36 \\
\hline Explained variance of $\mathrm{RE}$ effect $\mathrm{t}^{\mathrm{a}}$ & & & $3.7 \%$ & & $15.7 \%$ & \\
\hline
\end{tabular}

** $P<.01 ; * p<.05 ;+p<.1$

${ }^{a}$ The percentage refers to the extent to which the variance of the CEDs effects in Model 1 is explained. For instance, the explained cross-industry variance of the VE effect in Model $3=\{(1.66-0.02) / 1.66\} \times 100 \%=98.7 \%$ 
The variance of BE $(.65, p>.1)$ becomes non-significant, but the variance of $\operatorname{VE}(.97, p<.05)$ and $\operatorname{RE}(1.29, p<.01)$ remains significant. Finally, Model 3 shows that the crossindustry variance is explained by $98.7 \%$ for $\mathrm{VE}, 77.0 \%$ for $\mathrm{BE}$, and $92.2 \%$ for RE. The cross-firm variance is explained by $28.1 \%$ for VE, $69.4 \%$ for BE, and $15.7 \%$ for RE. Most of the cross-industry variance is explained, but the cross-firm variance is moderately explained.

\section{Robustness checks}

To test whether the results of Model 3 in Table 4 are robust (i.e., the 11 significant or marginally significant interactions of CEDs and industry- and firm-level characteristics), we conducted four robustness checks: (1) examining an alternative model with link(probit), (2) excluding commitment in the construct of RE because some argue that commitment is a dimension of loyalty, rather than a dimension of RE (e.g., Morgan and Hunt 1994), (3) using a smaller dataset (excluding one-third of the total sample) to examine coefficient reliability, and (4) including the interactions of CEDs. Most results of the robustness checks are consistent with those of Model 3. We reported the results of the robustness checks in Web Appendix F.

\section{Discussion}

\section{Summary of findings}

This study extends prior research on the differential effectiveness of loyalty strategies across industries and firms by systematically developing a framework of industry and firm characteristics as moderators. We used multiple sources of data to empirically examine how these contextual characteristics influence the role of CEDs in loyalty decisions. We also controlled for customer-level moderators. Our findings, summarized in Table 6, give a better understanding of (1) which contextual characteristics actually have a contingent impact on the link between CEDs and loyalty intentions and (2) which specific contexts render CEDs as more or less effective. As speculated in prior literature, most of the identified moderators (except market position) indeed have a contingent impact. Advertising expenditures constitute the most crucial moderator because they significantly influence VE and BE and marginally significantly influence RE. Three industry contexts (i.e., innovative markets, visibility to others, and complexity of purchase decisions) each influence two CEDs. Two industry contexts (i.e., competitive intensity and contractual settings) each influence one CED. However, the data do not provide support for the following contingent hypotheses: (1) innovative markets for the VE-loyalty link, (2) visibility to others for the BE-loyalty link, and (3) complexity of purchase decisions for the VE-loyalty and RE-loyalty links. In the following discussion, we provide potential explanations for these unsupported findings. We explain only the hypotheses for which the data provide no support. We do not explain the unfound exploration effects.

\section{Unsupported findings}

Innovative markets: VE We expected that VE would be important in innovative markets because firms in these markets aim to improve VE (Hauser et al. 2006), which should be an important criterion for customers when deciding to repurchase. However, we find that innovative markets do not exert a moderating effect on the link between VE and loyalty intentions. While we expect a positive moderating effect of innovative markets on $\mathrm{VE}$, it might also be cancelled out by a potential negative effect. A potential reason is that firms in innovative markets commonly aim to improve $\mathrm{VE}$, rendering the fulfillment of $\mathrm{VE}$ a basic requirement for firms trying to

Table 6 Summary of the results

\begin{tabular}{|c|c|c|c|c|c|c|}
\hline & \multicolumn{2}{|l|}{ VE } & \multicolumn{2}{|l|}{$\mathrm{BE}$} & \multicolumn{2}{|l|}{$\mathrm{RE}$} \\
\hline & Hypoth. & Result & Hypoth. & Result & Hypoth. & Result \\
\hline \multicolumn{7}{|l|}{ Industry characteristics } \\
\hline Competitive intensity & H1ve (-) & - & Explore & 0 & Explore & 0 \\
\hline Innovative markets & H2ve (+) & 0 & H2be $(+)$ & + & Explore & - \\
\hline Contractual settings & Explore & 0 & Explore & 0 & H3re (+) & + \\
\hline Visibility to others & H4ve (+) & + & H4be $(+)$ & 0 & H4re (-) & - \\
\hline Complexity of purchase decisions & H5ve (+) & - & H5be $(+)$ & + & H5re (+) & + \\
\hline \multicolumn{7}{|l|}{ Firm characteristics } \\
\hline Market position & Explore & 0 & Explore & 0 & Explore & 0 \\
\hline Advertising expenditures & H6ve (-) & - & H6be $(+)$ & + & Explore & $-^{\mathrm{a}}$ \\
\hline
\end{tabular}

0: no effect

${ }^{\text {a }}$ Marginally significant $(p<.1)$ 
survive in such markets (Fredericks and Salter 1995; Rust et al. 2000). This may indicate that customers perceive fewer differences in VE among firms in innovative markets and thus are less likely to employ VE as a comparison standard for differentiating firms in such markets (Slater 1997). In any case, additional research is required to understand the moderating role of innovative markets.

Visibility to others: BE Prior studies have widely assumed that $\mathrm{BE}$ is important in visible goods/services because it is more publicly noticeable than VE and RE (e.g., Fischer et al. 2010; Rust et al. 2000). However, our data do not confirm this expectation, implying that BE is not particularly important for respondents in visible goods/services. A potential explanation is the relative importance of signal credibility or self-identity - the two functions of BE-in customers' loyalty decisions (Erdem et al. 2006; Rust et al. 2000). We assume that customers focusing on the function of signal credibility may ignore the importance of $\mathrm{BE}$ being publicly noticeable, as signal credibility is more about evaluating the attributes of goods/services and reducing performance risk. In contrast, customers focusing on the function of self-identity may emphasize the importance of $\mathrm{BE}$ being publicly noticeable, as the relevance of $\mathrm{BE}$ in decision making is greater for social demonstrativeness and the need to make a good impression (Bearden and Rose 1990; Fischer et al. 2010). Further research could distinguish between the self-identity and risk-reducing roles of brands. In our limited measurement of BE, we did not make such a distinction.

Complexity of purchase decisions: VE and RE We hypothesized that complexity of the purchase decision would strengthen the effects of all CEDs. However, the findings were mixed. We found only a significant, positive moderating effect on the BE-loyalty link. Conversely, the effect of VE on loyalty intentions became weaker in the face of complexity, and this variable failed to show a moderating effect on the REloyalty link. The reasoning for these mixed results may derive from customers perceiving different sources of purchase decision complexity: the extensive amount of information required for choosing goods/services, on the one hand (Rust et al. 2000), and choices among too many competitors, on the other hand (Scheibehenne et al. 2010). These two sources imply a positive and negative moderating impact of purchase decision complexity, respectively. Our argument for the hypotheses derives from the first source (positive moderation), as research suggests that CEDs are crucial factors in reducing the complexity of purchase decisions (Rust et al. 2004; Vogel et al. 2008). Regarding the second source (negative moderation), customers tend to experience choice overload when confronted with too many competitors, which leads to difficulty in justifying preferences, less motivation to choose, and less ability to make optimal choices (Scheibehenne et al.
2010). As such, customers may be less able to accurately transfer their perceptions of firms into loyalty intentions. If so, the CEDs-loyalty link becomes weaker for customers with choice overload. Thus, to further validate the moderating role of purchase decision complexity on the CEDs-loyalty link, research should distinguish between the sources of complexity perceived by customers.

\section{Managerial implications}

Because resources are limited, "it is essential that firms identify their industry's success factors, paying more attention to the [CEDs] that drive customer choice, and perhaps paying less attention to the ones that don't" (Rust et al. 2000, p. 262). To achieve effective resource allocation, managers should define success factors in their own specific context.

Figure 2 provides managers across different services industries with information about the industry and firm characteristics that actually influence the effectiveness of CEDs and which CEDs are most and least effective in their own specific context. For example, Panel A shows that changes in loyalty intentions are 24.1, 6.9, and 15\% when firms are able to increase VE, BE, and RE, respectively, by one standard deviation. ${ }^{8}$ However, our findings indicate that not all industries and firms uniformly benefit from these numbers. Without taking the context into account, managers may be mistaken about the idiosyncratic effects of CEDs in specific contexts. Panels B, C, and D display the idiosyncratic effects of $\mathrm{VE}, \mathrm{BE}$, and RE across different industries and firms, respectively. We use Panel D (i.e., RE) as an illustrative example.

Panel D offers two insights into the idiosyncratic effects of $\mathrm{RE}$ across industries and firms. First, the following industry and firm characteristics do not influence the effectiveness of $\mathrm{RE}$ as changes in loyalty intentions in these characteristics remain at $15 \%$ (see Panel A): (1) competitive intensity, (2) complex purchase decisions, and (3) market position. In terms of contextual impact, these characteristics play a less important role in the effectiveness of RE strategies. Second, RE is more effective in contractual settings, as change in loyalty intentions rises from 15 to $24.8 \%$. However, RE is less effective in the following contexts as changes in loyalty intentions across all the industries are lower than 15\%: (1) innovative markets, (2) industries whose products are more visible to

\footnotetext{
${ }^{8}$ We follow the idea of Luo and Bhattacharya (2009) and visualize the extent to which loyalty intentions change by implementing CEDs strategies. Take VE, for example. We calculated changes in loyalty intentions when increasing VE by one standard deviation as follows:

$$
\frac{\beta_{1 m n} \times \text { one } S D \text { of } V E}{\text { variance of loyalty intentions }}=\frac{1.95 \times 1.09}{8.85}=0.241,
$$

where $\beta_{1 m n}$ is from Eq. 3 of the model specification and SD refers to the standard deviation of VE. To match the seven-point scale of CEDs, we divided loyalty intentions $(0-100)$ by 10 to get into the range between 0 and 10 . Thus, the variance of loyalty intentions is $(2.976)^{2}=8.85$.
} 
Fig. 2 Changes in loyalty intentions by implementing CEDs
A: Changes in loyalty intentions without the impact of industry and firm characteristics

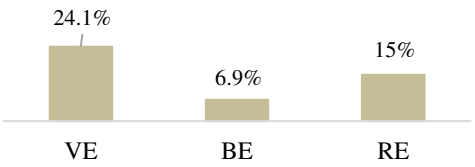

\section{B: Changes in loyalty intentions by VE across industries and firms}

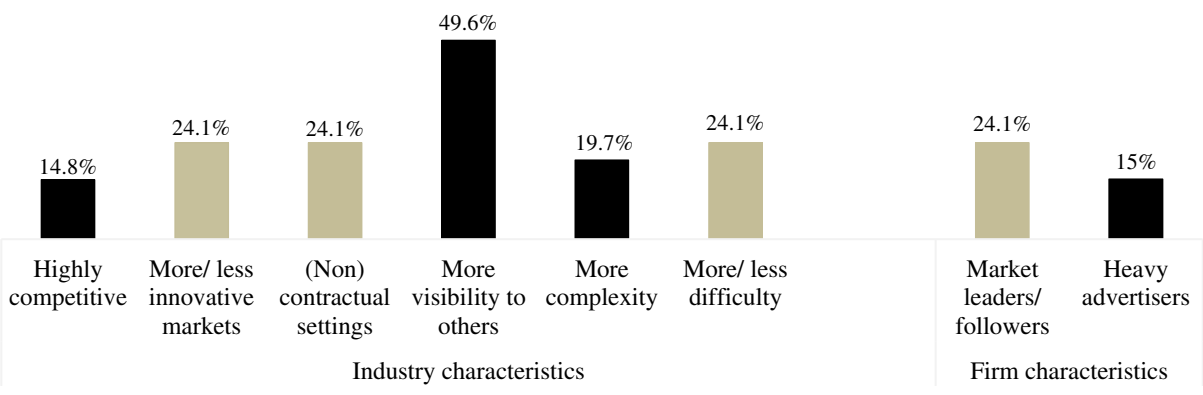

$\underline{\text { C: Changes in loyalty intentions by BE across industries and firms }}$

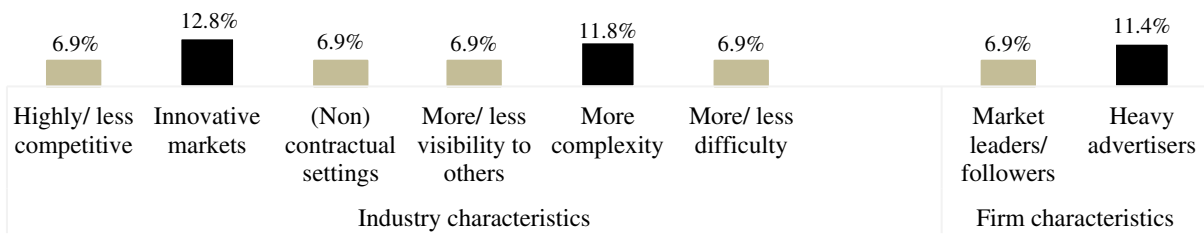

D: Changes in loyalty intentions by RE across industries and firms

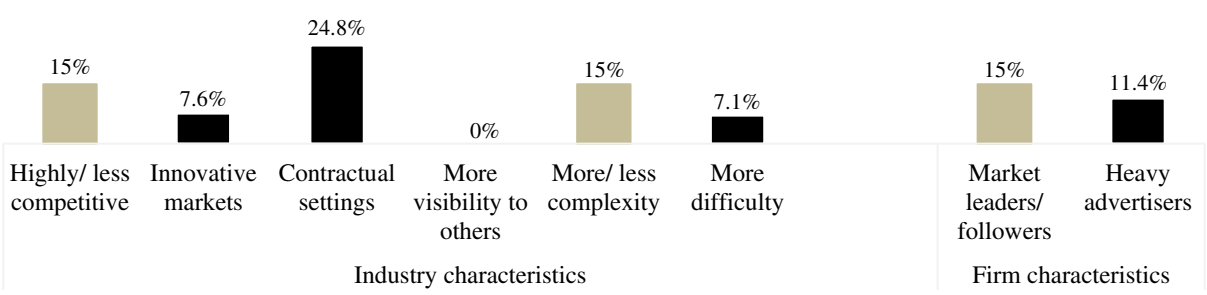

others, (3) industries in which customers have trouble evaluating quality, and (4) heavy advertisers. These results imply that similar RE strategies indeed create different levels of loyalty intentions in different industries and different firms.

Therefore, to effectively allocate resources, managers should not only consider the effectiveness of loyalty activities but also align those activities with the influential idiosyncrasies that define their firms' contexts. Ignoring these contexts may result in a sub-optimal allocation of resources and a failure to reach desired performance.

\section{Limitations and further research}

As with other empirical studies, our study has some limitations that provide avenues for further research. First, because we aimed to extend the Rust et al. (2000) model, we followed their method of using loyalty intentions, rather than behavioral loyalty, as the dependent variable. In fairness, it is not currently feasible to compare behavioral loyalty across industries for a large number of firms, as behavioral loyalty has different meanings across industries. However, we recognize that actual, observed loyalty behavior is the ultimate proof of loyalty and is more related to the metrics of firm performance (e.g., De Haan et al. 2015). In addition, although CMB is not a serious concern in our data, it does exist, and one remedy for CMB entails using behavioral loyalty. We thus encourage further research to uncover an adequate proxy of behavioral loyalty as a comparison criterion across industries.

Second, the large-scale dataset limits the number of items we could use for CEDs. Although Cronbach's $\alpha$ shows sufficient reliability for CEDs, we admit that more items per construct could have been used. For example, BE can be measured not only by being strong and innovative but also by being liked (e.g., Vogel et al. 2008). In addition, the 
measurements of CEDs are non-invariant across industries. Although we included five industry and two firm characteristics to account for measurement non-invariance (Davidov et al. 2012), we understand that it cannot be completely accounted for.

Third, we incorporated five rarely examined industry-level moderators in the customer equity model, as well as explored two firm-level moderators. This is an initial step, but additional industry and firm characteristics are required. For example, in cases in which market-oriented firms have invested a great deal in building relationships, will these firms benefit more from continuing their investments in CRM or from investing in alternative loyalty strategies, such as VE or BE? Another example we did not consider is the servicescape, which is a firm-level characteristic involving the physical environment in which goods or services are purchased.

Fourth, with regard to the scope of the research setting, the dataset is limited to business-to-consumer firms in services industries in the Netherlands. To further generalize our findings, researchers could test whether the uncovered moderating role of industry and firm characteristics emerge in other industries (e.g., B2B) and other countries. For example, some researchers argue that $\mathrm{B} 2 \mathrm{~B}$ customers tend to focus on partnership cooperation (e.g., Palmatier et al. 2006). This argument implies that the contextual contingencies may have less impact on the link between RE and loyalty intentions.

Lastly, our large-scale dataset is limited to cross-sectional variation and cannot examine changes of the moderating role of industry and firm characteristics over time. Given that the trend of the market environment is toward more intense competition and R\&D investment, it is important to know whether these industry characteristics gain more impact over time.

Acknowledgments The authors thank the Customer Insights Center (specifically the managing director Jelle Bouma) of the University of Groningen for supporting this research. They thank Metrixlab, MICompany, and ACNielsen for research and data-support. They also thank three anonymous JAMS reviewers and the AE for their insightful, helpful comments and suggestions. We also thank the current editor Robert W. Palmatier and the prior editor Tomas Hult for their support and comments.

Open Access This article is distributed under the terms of the Creative Commons Attribution 4.0 International License (http:// creativecommons.org/licenses/by/4.0/), which permits unrestricted use, distribution, and reproduction in any medium, provided you give appropriate credit to the original author(s) and the source, provide a link to the Creative Commons license, and indicate if changes were made.

\section{References}

Aurier, P., \& N'Goala, G. (2010). The differing and mediating roles of trust and relationship commitment in service relationship maintenance and development. Journal of the Academy of Marketing Science, 38(3), 303-325.

Bagozzi, R. P., \& Dholakia, U. M. (2006). Open source software user communities: a study of participation in Linux user groups. Management Science, 52(7), 1099-1115.

Bamberger, P. (2008). From the editors beyond contextualization: using context theories to narrow the micro-macro gap in management research. Academy of Management Journal, 51(5), 839-846.

Baum, C. F. (2008). Modeling proportions. The Stata Journal, 8(2), 299 303.

Bearden, W. O., \& Etzel, M. J. (1982). Reference group influence on product and brand purchase decisions. Journal of Consumer Research, 9(2), 183-194.

Bearden, W. O., \& Rose, R. L. (1990). Attention to social comparison information: an individual difference factor affecting consumer conformity. Journal of Consumer Research, 16(4), 461-471.

Bell, S. J., Auh, S., \& Smalley, K. (2005). Customer relationship dynamics: service quality and customer loyalty in the context of varying levels of customer expertise and switching costs. Journal of the Academy of Marketing Science, 33(2), 169-183.

Bergkvist, L., \& Rossiter, J. R. (2007). The predictive validity of multiple-item versus single-item measures of the same constructs. Journal of Marketing Research, 44(2), 175-184.

Böckenholt, U., \& Lehmann, D. (2015). On the limits of research rigidity: the number of items in a scale. Marketing Letters, 26(3), 257-260.

Bowen, D. E., \& Jones, G. R. (1986). Transaction cost analysis of service organization-customer exchange. Academy of Management Review, $11(2), 428-441$.

BrandZ (2015). Most valuable global brands. http:// 70b9b3c05396f2eb8737-3ea5707b8537ca9957a2ade7dd5cd831. r61.cf3.rackcdn.com/BZ_Global2015_Full.pdf. Accessed 9 Sept 2015.

Burnham, T. A., Frels, J. K., \& Mahajan, V. (2003). Consumer switching costs: a typology, antecedents, and consequences. Journal of the Academy of Marketing Science, 31(2), 109-126.

Chandrashekaran, M., Rotte, K., Tax, S. S., \& Grewal, R. (2007). Satisfaction strength and customer loyalty. Journal of Marketing, 44(1), 153-163.

Cooil, B., Keiningham, T. L., Aksoy, L., \& Hsu, M. (2007). A longitudinal analysis of customer satisfaction and share of wallet: investigating the moderating effect of customer characteristics. Journal of Marketing, 71(1), 67-83.

Davidov, E., Dülmer, H., Schlüter, E., Schmidt, P., \& Meuleman, B. (2012). Using a multilevel structural equation modeling approach to explain cross-cultural measurement noninvariance. Journal of Cross-Cultural Psychology, 43(4), 558-575.

De Haan, E., Verhoef, P. C., \& Wiesel, T. (2015). The predictive ability of different customer feedback metrics for retention. International Journal of Research in Marketing, 32(2), 195-206.

De Luca, L. M., \& Atuahene-Gima, K. (2007). Market knowledge dimensions and cross-functional collaboration: examining the different routes to product innovation performance. Journal of Marketing Research, 71(1), 95-112.

Dorotic, M., Bijmolt, T. H. A., \& Verhoef, P. C. (2012). Loyalty programs: current knowledge and research directions. International Journal of Management Reviews, 14(3), 217-237.

Dowling, G. R., \& Uncles, M. D. (1997). Do customer loyalty programs really work? Sloan Management Review, 38(4), 71-82.

Ehrenberg, A. S. C., Goodhardt, G. J., \& Barwise, T. P. (1990). Double jeopardy revisited. Journal of Marketing, 54(3), 82-91.

Eisenbeiss, M., Cornelißen, M., Backhaus, K., \& Hoyer, W. D. (2014). Nonlinear and asymmetric returns on customer satisfaction: do they vary across situations and consumers? Journal of the Academy of Marketing Science, 42(3), 242-263.

Erdem, T., \& Swait, J. (1998). Brand equity as a signaling phenomenon. Journal of Consumer Psychology, 7(2), 131-157. 
Erdem, T., Swait, J., \& Valenzuela, A. (2006). Brands as signals: a crosscountry validation study. Journal of Marketing, 70(1), 34-49.

Evans, M. G. (1991). The problem of analyzing multiplicative composites: interactions revisited. American Psychologist, 46(1), 6-15.

Fader, P. S., \& Hardie, B. G. S. (2007). How to project customer retention. Journal of Interactive Marketing, 21(1), 76-90.

Feldman, J. M., \& Lynch, J. G. (1988). Self-generated validity and other effects of measurement on belief, attitude, intention, and behavior. Journal of Applied Psychology, 73(3), 421-435.

Fischer, M., Völckner, F., \& Sattler, H. (2010). How important are brands? A cross-category, cross-country study. Journal of Marketing Research, 47(5), 823-839.

Fischer, M., Shin, H. S., \& Hanssens, D. M. (2016). Brand performance volatility from marketing spending. Management Science, 62(1), 197-215.

Fisher, R. J., \& Price, L. L. (1992). An investigation into the social context of early adoption behavior. Journal of Consumer Research, 19(3), 477-486.

Fornell, C., \& Larcker, D. F. (1981). Structural equation models with unobservable variables and measurement error: algebra and statistics. Journal of Marketing Research, 18(3), 382-388.

Frank, B., Enkawa, T., \& Schvaneveldt, S. J. (2014). How do the success factors driving repurchase intent differ between male and female customers? Journal of the Academy of Marketing Science, 42(2), $171-185$.

Fredericks, J. O., \& Salter, J. M., II. (1995). Beyond customer satisfaction. Management Review, 84(5), 29-32.

Gatignon, H. (1984). Competition as a moderator of the effect of advertising on sales. Journal of Marketing Research, 21(4), 387-398.

Gulati, R. (1995). Does familiarity breed trust? The implications of repeated ties for contractual choice in alliances. The Academy of Managerial Journal, 38(1), 85-112.

Gustafsson, A., Johnson, M. D., \& Roos, I. (2005). The effects of customer satisfaction, relationship commitment dimensions, and triggers on customer retention. Journal of Marketing, 69(4), 210-218.

Hauser, J., Tellis, G. J., \& Griffin, A. (2006). Research on innovation: a review and agenda for marketing science. Marketing Science, 25(6), $687-717$.

Hoeffler, S., \& Keller, K. L. (2003). The marketing advantages of strong brands. Journal of Brand Management, 10(6), 421-445.

Homburg, C., \& Giering, A. (2001). Personal characteristics as moderators of the relationship between customer satisfaction and loyalty: an empirical analysis. Psychology \& Marketing, 18(1), 43-66.

Homburg, C., Koschate, N., \& Hoyer, W. D. (2006). The role of cognition and affect in the formation of customer satisfaction: a dynamic perspective. Journal of Marketing, 70(3), 21-31.

Hox, J. (2002). Multilevel analysis: Techniques and applications. London: Lawrence Erlbaum Associations.

Johns, G. (2006). The essential impact of context on organizational behavior. Academy of Management Review, 31(2), 386-408.

Kaul, A., \& Wittink, D. R. (1995). Empirical generalizations about the impact of advertising on price sensitivity and price. Marketing Science, 14(3), G151-G160.

Keiningham, T. L., Frennea, C. M., Aksoy, L., Buoye, A., \& Mittal, V. (2015). A five-component customer commitment model: implications for repurchase intentions in goods and services industry. Journal of Service Research, 18(4), 433-450.

Keller, K. L. (1993). Conceptualizing, measuring, and managing customer-based brand equity. Journal of Marketing, 57(1), 1-22.

Knapp, A. K., Hennig-Thurau, T., \& Mathys, J. (2014). The importance of reciprocal spillover effects for the valuation of bestseller brands: introducing and testing a contingency model. Journal of the Academy of Marketing Science, 42(2), 205-221.

Kumar, V., Pozza, I. D., \& Ganesh, J. (2013). Revising the satisfactionloyalty relationship: empirical generalizations and directions for future research. Journal of Retailing, 89(3), 246-262.
Lemon, K. N., Rust, R. T., \& Zeithaml, V. A. (2001). What drives customer equity? Marketing Management, 10(1), 20-25.

Liang, H., Saraf, N., Hu, Q., \& Xue, Y. (2007). Assimilation of enterprise systems: the effect of institutional pressures and the mediating role of top management. MIS Quarterly, 31(1), 59-87.

Lindell, M. K., \& Whitney, D. J. (2001). Accounting for common method variance in cross-sectional research designs. Journal of Applied Psychology, 86(1), 114-121.

Littler, D., \& Melanthiou, D. (2006). Consumer perceptions of risk and uncertainty and the implications for behavior towards innovative retail services: the case of internet banking. Journal of Retailing and Consumer Services, 13(6), 431-443.

Longshore, D., \& Prager, J. (1985). The impact of school desegregation: a situational analysis. Annual Review of Sociology, 11, 75-91.

Luo, X., \& Bhattacharya, C. B. (2009). The debate over doing good: corporate social performance, strategic marketing levers, and firmidiosyncratic risk. Journal of Marketing, 73(6), 198-213.

Mägi, A. W. (2003). Share of wallet in retailing: the effects of customer satisfaction, loyalty cards and shopper characteristics. Journal of Retailing, 79(2), 97-106.

Mauri, A. J., \& Michaels, M. (1998). Firm and industry effects within strategic management: an empirical examination. Strategic Management Journal, 19(3), 211-219.

McAlister, L., Srinivasan, R., \& Kim, M. C. (2007). Advertising, research and development, and systematic risk of the firm. Journal of Marketing, 71(1), 35-48.

Mende, M., Bolton, R. N., \& Bitner, M. J. (2013). Decoding customerfirm relationships: how attachment styles help explain customers' preference for closeness, repurchase intentions, and changes in relationship breadth. Journal of Marketing Research, 50(1), 125-142.

Menguc, B., \& Auh, S. (2006). Creating a firm-level dynamic capability through capitalizing on market orientation and innovativeness. Journal of the Academy of Marketing Science, 34(1), 63-73.

Mitra, A., \& Lynch, J. G., Jr. (1995). Toward a reconciliation of market power and information theories of advertising effects on price elasticity. Journal of Consumer Research, 21(4), 644-659.

Mittal, V., \& Kamakura, W. A. (2001). Satisfaction, repurchase intent, and repurchase behavior: investigating the moderating effect of customer characteristics. Journal of Marketing Research, $38(1), 131-142$.

Mizik, N., \& Jacobson, R. (2003). Trading off between value creation and value appropriation: the financial implications of shifts in strategic emphasis. Journal of Marketing, 67(1), 63-76.

Molloy, J. C., Ployhart, R. E., \& Wright, P. M. (2010). The myth of "the" micro-macro divide: bridging system-level and disciplinary divides. Journal of Management, 37(2), 581-609.

Moore, D. S., \& McCabe, G. P. (2003). Introduction to the practice of statistics. New York: W. H. Freeman and Company.

Morgan, R. M., \& Hunt, S. D. (1994). The commitment-trust theory of relationship marketing. Journal of Marketing, 58(3), 20-38.

Nagengast, L., Evanschitzky, H., Blut, M., \& Rudolph, T. (2014). New insights in the moderating effect of switching costs on the satisfaction-repurchase behavior link. Journal of Retailing, 90(3), 408-427.

Nijssen, E., Singh, J., Sirdeshmukh, D., \& Holzmüeller, H. (2003). Investigating industry context effects in consumer-firm relationships: preliminary results from a dispositional approach. Journal of the Academy of Marketing Science, 31(1), 46-60.

Ou, Y. C., de Vries, L., Wiesel, T., \& Verhoef, P. C. (2014). The role of consumer confidence in creating customer loyalty. Journal of Service Research, 17(3), 339-354.

Palmatier, R. W., Dant, R. P., Grewal, D., \& Evans, K. R. (2006). Factors influencing the effectiveness of relationship marketing: a meta-analysis. Journal of Marketing, 70(4), 136-153. 
Palmatier, R. W., Jarvis, C. B., Bechkoff, J. R., \& Kardes, F. R. (2009). The role of customer gratitude in relationship marketing. Journal of Marketing, 73(5), 1-13.

Park, C. W., MacInnis, D. J., Priester, J., Eiseingerich, A. B., \& Iacobucci, D. (2010). Brand attachment and brand attitude strength: conceptual and empirical differentiation of two critical brand equity drivers. Journal of Marketing, 74(6), 1-17.

Pieters, R., \& Wedel, M. (2004). Attention capture and transfer in advertising: brand, pictorial, and text-size effects. Journal of Marketing, 68(2), 36-50.

Pleatsikas, C., \& Teece, D. (2001). The analysis of market definition and market power in the context of rapid innovation. International Journal of Industrial Organization, 19(5), 665-693.

Podsakoff, P. M., MacKenzie, S. B., Lee, J. Y., \& Podsakoff, N. P. (2003). Common method biases in behavioral research: a critical review of the literature and recommended remedies. Journal of Applied Psychology, 88(5), 879-903.

Reimann, M., Schilke, O., \& Thomas, J. S. (2010). Customer relationship management and firm performance: the mediating role of business strategy. Journal of the Academy of Marketing Science, 38(3), 326-346.

Rooney, J. (2014). Google beats apple as BrandZ most valuable global brand. Forbes. http://www.forbes.com/sites/jenniferrooney/2014/ 05/20/google-beats-apple-as-brandz-most-valuable-global-brand/. Accessed 9 Sept 2015.

Rust, R. T., Zeithaml, V. A., \& Lemon, K. N. (2000). Driving customer equity: How customer lifetime value is reshaping corporate strategy. New York: Free Press.

Rust, R. T., Lemon, K. N., \& Zeithaml, V. A. (2004). Return on marketing: using customer equity to focus marketing strategy. Journal of Marketing, 68(1), 109-127.

Scheibehenne, B., Greifeneder, R., \& Todd, P. M. (2010). Can there ever be too many options? A meta-analytic review of choice overload. Journal of Consumer Research, 37, 409-425.

Seiders, K., Voss, G. B., Grewal, D., \& Godfrey, A. L. (2005). Do satisfied customers buy more? Examining moderating influences in a retailing context. Journal of Marketing, 69(4), 26-43.

Selnes, F., \& Gønhaug, K. (2000). Effects of supplier reliability and benevolence in business marketing. Journal of Business Research, 49(3), 259-271.
Slater, S. F. (1997). Developing a customer value-based theory of the firm. Journal of the Academy of Marketing Science, 25(2), 162-167.

Slater, S. F., \& Narver, J. C. (1994). Does competitive environment moderate the market orientation-performance relationship? Journal of Marketing, 58(1), 46-55.

Urbany, J. E., Dickson, P. R., \& Wilkie, W. L. (1989). Buyer uncertainty and information search. Journal of Consumer Research, 16(2), 208-215.

Vakratsas, D., \& Ambler, T. (1999). How advertising works: what do we really know? Journal of Marketing, 63(1), 26-43.

Verhoef, P. C. (2003). Understanding the effect of customer relationship management efforts on customer retention and customer share development. Journal of Marketing, 67(4), 30-45.

Verhoef, P. C., \& Leeflang, P. S. H. (2009). Understanding the marketing department's influence within the firm. Journal of Marketing, 73(2), $14-37$.

Verhoef, P. C., Franses, P. H., \& Hoekstra, J. C. (2002). The effects of relational constructs on customer referrals and number of services purchased from a multiservice provider: does age of relationship matter? Journal of the Academy of Marketing Science, 30(3), 202-216

Verhoef, P. C., Langerak, F., \& Donkers, B. (2007). Understanding brand and dealer retention in the new car market: the moderating role of brand tier. Journal of Retailing, 83(1), 97-113.

Vogel, V., Evanschitzky, H., \& Ramaseshan, B. (2008). Customer equity drivers and future sales. Journal of Marketing, 72(6), 98-108.

Voss, G. B., Godfrey, A., \& Seiders, K. (2010). How complementarity and substitution alter the customer satisfaction-repurchase link. Journal of Marketing, 74(6), 111-127.

Watson, G. F., IV, Beck, J. T., Henderson, C. M., \& Palmatier, R. W. (2015). Building, measuring, and profiting from customer loyalty. Journal of the Academy of Marketing Science, 43(6), 790-825.

Wirtz, J., Xiao, P., Chiang, J., \& Malhotra, N. (2014). Contrasting the drivers of switching intent and switching behavior in contractual service settings. Journal of Retailing, 90(4), 463-480.

Wood, R., \& Bandura, A. (1989). Social cognitive theory of organizational management. Academy of Management Review, 14(3), $361-384$. 